\title{
The syntax of anaphoric possessives in Hungarian
}

\author{
Éva Dékány
}

Received: 17 February 2013 / Accepted: 25 February 2014 / Published online: 5 February 2015

(C) Springer Science+Business Media Dordrecht 2015

\begin{abstract}
Starting with the seminal work of Szabolcsi, morphologically unmarked and Dative-marked possessors in Hungarian have been the subject of rich investigation. Anaphoric possessive constructions, however, have remained poorly researched. In these possessives the possessor bears the mysterious - $e$ suffix and the covert possessum is interpreted under identity with an antecedent. This paper presents new evidence in favour of Bartos' (2001) analysis of anaphoric possessives, which holds that $-e ́$ is the Genitive case. I further argue that anaphoric possessives in Hungarian involve a pro-form rather than deletion of a lexical noun, and this accounts for the restricted modification of the possessum.
\end{abstract}

Keywords Possessive Construction - Anaphoric possessum · Ellipsis · Genitive Case $\cdot$ Demonstrative Concord

\section{Introduction}

Hungarian is well-known to have two different kinds of possessors. Morphologically unmarked possessors follow the definite article (1), while Dative-marked possessors precede it (2). Only the latter type can be extracted from the DP (Szabolcsi 1983, 1992, 1994; Laczkó 1995; Dikken 1999; Bartos 1999, Chaps. 2.1 and 4.3.2; Bartos 2000; É. Kiss 2000, 2002, Chap. 7).

This paper is a thoroughly revised version of Chap. 8.7 of my $\mathrm{PhD}$ dissertation submitted to CASTL, the University of Troms $\emptyset$. Work on this article was supported by the Hungarian Scientific Research Fund's grant OTKA NK 100804 (CGR-H), and the postdoctoral fellowship programme of the Hungarian Academy of Sciences under Grant No. PD-008/2014.

É. Dékány $(\varangle)$

Research Institute for Linguistics, Hungarian Academy of Sciences, Budapest, Hungary

e-mail: dekany.eva@nytud.mta.hu 
(1)

a te csont-od

the you.SG bone-2SG

'your(sg) bone'

(2)
a. János-nak a csont-ja
John-DAT the bone-POSS
'John's bone'
b. János-nak $i$ el-tör-t
$\left[\mathrm{t}_{i}\right.$ a csont-ja]
John-DAT away-break-PST.3SG the bone-POSS
'John's bone has broken.'

Morphologically unmarked and Dative possessors have been the subject of rich investigation.

This paper focuses on a third, as yet poorly researched possessive construction in Hungarian: anaphoric possessives. In anaphoric possessives the possessed noun, the head of the whole nominal phrase, is not pronounced, and its reference has to be recovered from the context (cf. English mine, my old ones, this is John's). Interestingly, the possessor in Hungarian anaphoric possessives cannot be either morphologically unmarked or Dative-marked. Instead, it has to bear the -é suffix. ${ }^{1}$

$$
\begin{aligned}
& \text { a fiú-é } \\
& \text { the boy-é } \\
& \text { 'the boy's one' }
\end{aligned}
$$

Possessors with -é are restricted to anaphoric noun phrases (4) and predicative position (5). Morphologically unmarked and Dative-marked possessors, on the other hand, only occur in non-anaphoric noun phrases.
János barát-ja
el-ment,
Péter-é itt marad-t.
John friend-POSS away-go.PST.3SG Peter-é here stay-PST.3SG

'John's friend has left, Peter's one stayed here.'
Ez a csont János-é.
this the bone John-é
(6) *János-é (a) csont-ja
John-é the bone-POSS
'This bone is John's.'
'John's bone'

An intriguing property of Hungarian anaphoric possessives is that the modification possibilities of the anaphoric possessum are extremely limited: adjectives, classifiers, numerals, demonstratives, and adnominal participial clauses cannot occur in this construction. Compare the non-elliptical possessive constructions in (7) with the anaphoric construction in (8).

(7) Non-elliptical possessums freely admit modification

a. János eme tegnap talál-t két darab fehér csont-ja

John this yesterday find-PRT two CL white bone-POSS

'these two white bones of John's found yesterday'

\footnotetext{
${ }^{1}$ The Hungarian literature refers to -é under two different labels: birtokjel 'possessum suffix' (Korompay 1992; Bartos 1999, 2001; Mártonfi 2004), and birtokjelölő 'possessum marker' (Rebrus 2000:776). I will not take over either of them. I will use the neutral term ' $-e ́$ (morpheme/suffix)' instead, and will gloss it as '-é'. 
b. János-nak ez a tegnap talál-t két darab fehér csont-ja John-DAT this the yesterday find-PRT two CL white bone-POSS 'these two white bones of John's found yesterday'

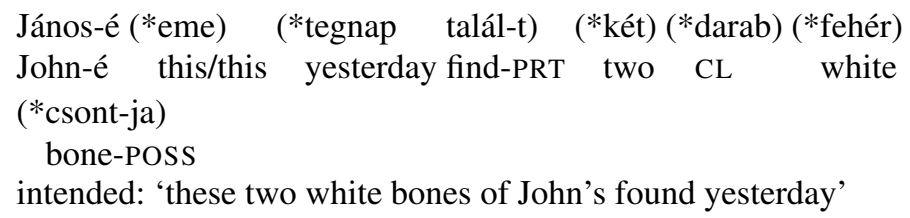

This property is noteworthy because the modification of unpronounced/anaphoric nouns in Hungarian is unrestricted as long as the noun in question is not possessed.
a. Kér-em ez-t a két darab fehér csont-ot. want-1SG this-ACC the two CL white bone-ACC 'I'd like these two white bones.'
b. Kér-em ez-t a két darab fehér-et. want-1SG this-ACC the two CL white-ACC 'I'd like these two white ones.'

Furthermore, it is not the case that the modification of anaphoric possessums is universally restricted: anaphoric possessums in English, for instance, freely admit all kinds of modifiers that non-anaphoric noun phrases do.

$$
\text { John's two white ones/these two white ones of John's found yesterday }
$$

The second interesting property of Hungarian anaphoric possessives is that the range of nominal suffixes that can occur in the construction is also restricted. The nominal suffixes available to a plain non-anaphoric possessed noun are illustrated in (11).
az én csont-ja-i-m-at
the I bone-POSS-PL-1SG-ACC
'my bones'

The possessum is obligatorily followed by the so-called possessedness suffix -ja/-je/ $-a /-e$ (this morpheme will be introduced in detail in Sect. 2). If the possessum is plural, the next suffix is the plural marker. The plural is followed by the possessive agreement (for the $\phi$-features of pronominal possessors), and the last suffix is the case marker.

In anaphoric possessives, the possessedness suffix -ja/-je/-a/-e must be absent (13). In other words, $-e ́$ possessors are in complementary distribution with the possessedness suffix.
János-(nak a) csont-*(ja)
John-DAT the bone-POSS
'John's bone'

János-é-(*ja)

John-é-POSS

'John's one' 
At the same time, other suffixes that possessums may bear (the plural marker, possessive agreement, and case) are retained in anaphoric possessives. Given that in this case the possessum has no phonological form, the suffixes in question lean onto the -é marked possessor for phonological support (15). ${ }^{2}$

$$
\begin{aligned}
& \text { a ti csont-ja-i-tok-at } \\
& \text { the you(pl) bone-POSS-PL-2sG-ACC } \\
& \text { 'your(pl) bones' }
\end{aligned}
$$

$$
\begin{aligned}
& \text { a ti-é-i-tek-et } \\
& \text { the you(pl)-é-PL-2sG-ACC } \\
& \text { 'your(pl) ones' }
\end{aligned}
$$

The third intriguing property of -é is the following: when the -é marked possessor has a demonstrative modifier, -é has to appear on the demonstrative, too.

$$
\begin{aligned}
& \text { ez a fiú } \\
& \text { this the boy } \\
& \text { 'this boy' }
\end{aligned}
$$

$$
\begin{aligned}
& \text { ez-é a fiú-é } \\
& \text { this-é the boy-é } \\
& \text { 'this boy's one' }
\end{aligned}
$$

Apart from -é, only number, case markers, and case-like postpositions (also called inflecting or dressed postpositions) participate in demonstrative concord (these postpositions are morphologically free case markers, see Sect. 3.1). It is not obvious whether -é forms a natural class with the $\phi$-feature number and case, and if so, how.

$$
\begin{aligned}
& \text { ez a fiú } \\
& \text { this the boy } \\
& \text { 'this boy' } \\
& \text { ez a fa } \\
& \text { this the tree } \\
& \text { 'this tree' }
\end{aligned}
$$

ez-ek-et a fiú-k-at this-PL-ACC the boy-PL-ACC 'these boys'

ez alatt a fa alatt this under the tree under 'under this tree'

Kugler (2000:181) characterizes the demonstrative concord in (17) as sajátos, a magyar nyelvre jellemzó egyeztetés ("a special type of agreement characterising only Hungarian"). Zsigmond Simonyi, the great 19th century Hungarian linguist, stated that he knew no similar morpheme in other languages (Simonyi 1914:193). The view that $-e ́$ is a special morpheme that has no exact equivalents in other languages is also shared by the non-generative, descriptively-oriented work of Korompay (1992:350), Fodor (1999:139), and Mártonfi (2004:71).

\footnotetext{
${ }^{2}$ According to Kornai (1989), in spoken Hungarian the plural marker, too, is absent in anaphoric possessives. Compare the standard Hungarian (i) with the spoken Hungarian (ii):

(i) a hal-ak a barát-om-é-i the fish-PL the friend-1SG-é-PL 'the fish(pl) are my friend's'

(ii) \%a hal-ak a barát-om-é the fish-PL the friend-1SG-é 'the fish(pl) are my friend's' (Kornai 1989:7)
} 
Explicit discussion of -é possessors is rare in the literature. The suffix -é is taken to be a pro-form (Laczkó 2007), or an incarnation of the functional head that introduces possessors in the structure (the so-called Poss head, cf. Bartos 1999), or it is taken to be the Genitive case marker (Bartos 2001). While certain aspects of the distribution of -é have been successfully tackled in the previous approaches, the totality of facts surrounding -é possessors has resisted a satisfactory explanation. It is the aim of this article to offer a comprehensive analysis of -é possessors and to show that -é is not nearly as exceptional as Simonyi, Kugler, and others have thought. Specifically, -é is the Genitive case marker in Hungarian. The discussion will also bear on the pro vs. deletion analysis of nominal ellipsis.

This paper is structured as follows. Section 2 sets the scene for the analysis by familiarizing the English speaking reader with possessive morphology and DP structure in Hungarian. In Sect. 3 I present the syntactic properties of -é in detail. The previous generative analyses of -é are summarized in Sect. 4. In Sect. 5 I argue that the morpheme -é is the Genitive case, and show how this accounts for certain properties of -é. In Sect. 6 I argue that Hungarian anaphoric possessives contain a pro-form in the position of the possessum, and this is key in accounting for their restricted modification. Section 7 summarizes the analysis and offers some concluding remarks.

\section{Possessive morphology in Hungarian}

This section gives a short introduction to the structure of possessed noun phrases and to Hungarian possessive morphology in non-anaphoric possessives. Familiarity with these data and structures will help the reader to understand how -é possessives are different from non-anaphoric possessives, and to appreciate the arguments presented in the paper.

The order of phrasal modifiers in the Hungarian DP is rigid and corresponds to what Cinque (2005) identifies as the base generated order Dem $>$ Num $>$ Adj $>$ N.

ez-t a hét üreges csont-ot

this-ACC the seven hollow bone-ACC

'these seven hollow bones'

Possessums bear the possessedness suffix $-j a /-j e /-a /-e$.
János csont-ja
John bone-POSS
'John's bone'

This morpheme is the spellout of a contentful functional head in the nominal functional hierarchy (not an agreement morpheme). The literature refers to this head as Poss (Szabolcsi 1994; Bartos 1999, 2000; É. Kiss 2002). The function of Poss is to introduce the possessor into the structure ${ }^{3}$ and to establish the possessive relation-

\footnotetext{
${ }^{3}$ Bartos (1999) argues that possessors of event nominals are merged in NP. They get their theta-role there, and later on move to spec, PossP. This detail need not concern us here.
} 
ship between the possessor and the possessum (Mel'čuk 1973; Bartos 1999; Dékány 2011).

The position of PossP in the functional hierarchy can be probed by the relative ordering of $-j a /-j e /-a /-e$ and other nominal suffixes. This suffix cannot be preceded by any other inflectional suffix, and it is followed by the plural morpheme.

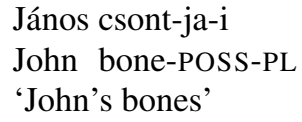

As the plural morpheme is located in the head of NumP (cf. Ritter 1991, 1992), by Baker's (1985) Mirror Principle PossP is lower in the structure than NumP.

$$
\text { NumP }>\text { PossP }>\text { NP }
$$

The possessed noun agrees for the $\phi$-features of pronominal possessors (regardless of whether the possessor is unmarked or Dative-marked). The agreement morpheme in third person singular is zero, but its presence can be detected by various tests (see Bartos 1999 and summaries of his arguments in É. Kiss 2002 and Csirmaz 2006). The possessive agreement suffix and the possessedness suffix -ja/-je/-a/-e flank the plural marker. ${ }^{4}$
a. csont-ja-i-m-at
bone-POSS-PL-1SG-ACC
'my bones'
b. csont-ja-i-d-at
bone-POSS-PL-2SG-ACC
'your bones'
c. csont-ja-i- $\emptyset$-t
bone-POSS-PL-3SG-ACC
'his bones'
d. csont-ja-i-nk-at bone-POSS-PL-1PL-ACC 'our bones'
e. csont-ja-i-tok-at bone-POSS-PL-2PL-ACC 'your bones'
f. csont-ja-i-k-at bone-POSS-PL-3PL-ACC 'their bones'

\footnotetext{
${ }^{4}$ When the possessed noun is morphologically singular, the Num head has no overt exponent, so the pos-
sessedness marker -ja/-je/- $a$ /- $e$ and the agreement suffix end up being adjacent. In this case, if the possessor

${ }^{4}$ When the possessed noun is morphologically singular, the Num head has no overt exponent, so the pos-
sessedness marker -ja/-je/-a/-e and the agreement suffix end up being adjacent. In this case, if the possessor is first or second person, the two suffixes are fused (Bartos 2000, 674-683; Rebrus 2000, 776-777, 922931; Kiefer 2000, 590-598). Hence (ia), (ib), (id), and (ie) feature just a single possession-related suffix.

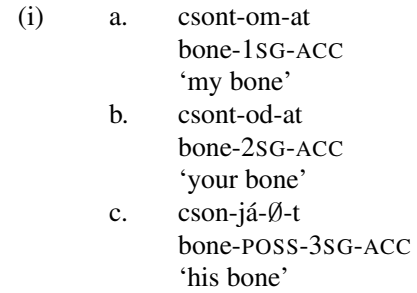
(a)
(i) csont-om-at bone-1SG-ACC
d. csont-unk-at bone-1PL-ACC 'our bone'
e. csont-otok-at bone-2PL-ACC 'your bone'
f. csont-j-uk-at bone-POSS-3PL-ACC 'their bone'


The phrase that hosts the agreement features is standardly thought to be projected by the agreement features themselves, and this projection is labelled as AgrP (Szabolcsi 1994; Bartos 1999; É. Kiss 2002). However, I follow the latest Minimalist thinking on agreement features and assume that they bundle with independently motivated functional heads rather than projecting their own phrase (Chomsky 2000, 2001; Julien 2002). Therefore I do not take over the established label; I call this phrase Poss 2 instead. Since the agreement suffix follows the plural suffix, Poss 2 is higher in the structure than NumP. ${ }^{5}$

$$
\text { Poss2P }>\text { NumP }>\text { PossP }>\text { NP }
$$

Possessors move out of their base-position in spec, PossP and land in the left periphery of the DP. Their surface position depends on their case-marking. Morphologically unmarked possessors follow the definite article (28), so they land in a position below DP. We can be sure that the article in (28) modifies the head noun csont and does not form a constituent with the possessor ô because pronouns in Hungarian cannot combine with the definite article (29).

az ő (tegnap talál-t) három csont-ja the he yesterday find-PRT three bone-POSS 'his three bones (found yesterday)'

*az én/te/ő/mi/ti/ők the I/you(sg)/he/we/you(pl)/they

Szabolcsi (1994), Bartos (1999) and É. Kiss (2002) identify the surface position of unmarked possessors as the specifier of Poss2 (their AgrP). I will follow this analysis here. The structure of a possessive construction with an unmarked possessor is illustrated in (31). (Note that -é possessors have the same surface position as unmarked possessors.)

az én csont-ja-i-m

the I bone-POSS-PL-1SG

'my bones'

\footnotetext{
${ }^{5} \mathrm{~A}$ reviewer would like me to comment on the fact that there is a NumP in (27) but at the same time I adopt the Chomsky-Julien approach to number (and person) agreement and so take number agreement not to project its own phrase. The number feature that projects the NumP (27) and the number agreement feature that tracks the number of the possessor are distinct types of features. The latter is an uninterpretable feature that enters the derivation without a value (uNum), and gets a value in the course of the derivation via probing the possessor. The number feature that projects the NumP of (27), on the other hand, is an interpretable feature (its semantic contribution is to make the noun singular or plural) that enters the derivation with an inherent $+/-$ plural value. In sum, the number feature in the head of NumP of (27) is not an agreement feature, and this is why it projects its own phrase. Not only does NumP have an interpretable number feature it its head, but it also hosts numerals in its specifier.
} 
(31)

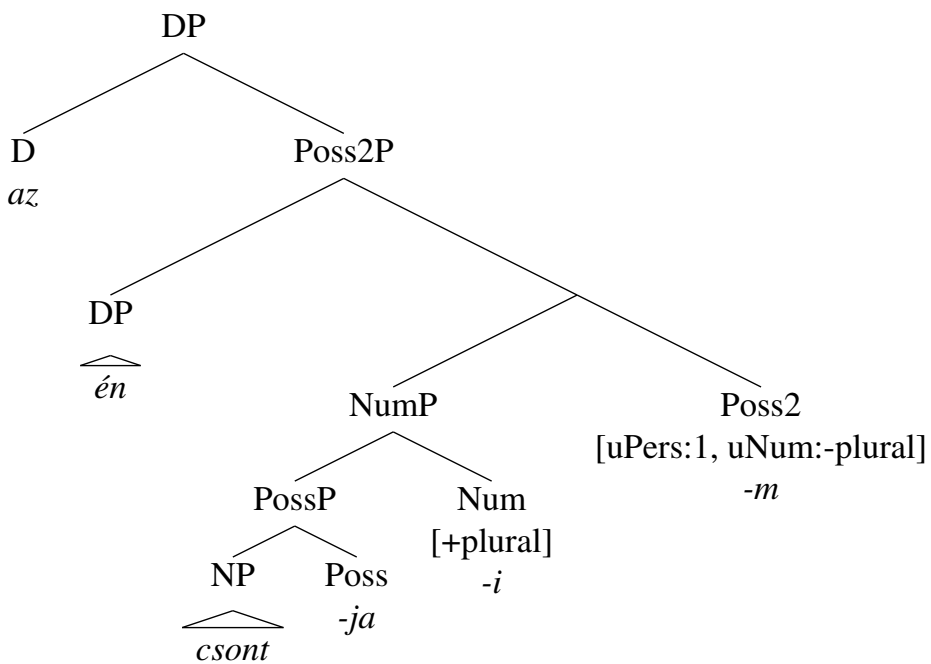

Dative possessors target a position higher than unmarked possessors: they precede the definite article and demonstratives.
János-nak a csont-ja
John-DAT the bone-POSS
'John's bone'

János-nak ez a csont-ja John-DAT this the bone-POSS 'this bone of John's'

These possessors are either taken to be adjoined to DP (É. Kiss 1998) or to sit in the specifier of a DP-internal TopP (É. Kiss 2000, 2002). For the sake of concreteness, I will treat them as adjuncts, but for our purposes nothing hinges on their exact position. The structure of a possessive construction with a Dative-marked possessor is illustrated in (35).
nek-em a csont-ja-i-m
DAT-1SG the bone-POSS-PL-1SG
'my bones' 


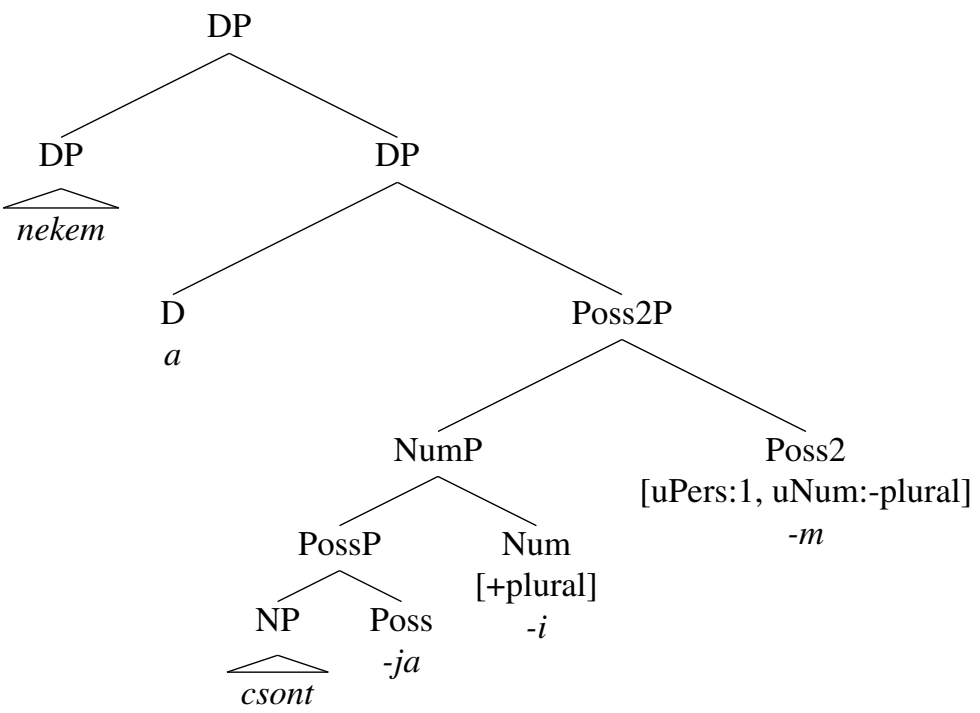

(36) summarizes the hierarchy of DP-internal functional projections relevant for possessives.

$$
\text { dative possessor }>\text { DP }>\text { Poss } 2 \mathrm{P}>\text { NumP }>\text { PossP }>\text { NP }
$$

\section{The distribution of $-e ́$ possessives}

In Hungarian anaphoric possessive constructions the possessor bears the -é suffix. There is no lexical noun in the position of possessum; the possessum is interpreted anaphorically. These constructions have five syntactic properties that an adequate analysis has to account for. Of these, three properties are related to the -é suffix: (i) -é is restricted to possessors in anaphoric noun phrases, (ii) -é cannot occur on Dative possessors, and (iii) -é takes part in demonstrative concord. The remaining two properties are related to the anaphoric possessum: (iv) it cannot take the possessedness suffix $-j a /-j e /-a /-e$, and (v) its modification is highly restricted. These properties have been mentioned in the previous discussion, and they will be explained in full below.

\subsection{The -é suffix and the -é possessor}

(I) Non-anaphoric possessives feature only morphologically unmarked or Dativemarked possessors.

$$
\begin{aligned}
& \text { János kard-ja } \\
& \text { John sword-Poss } \\
& \text { 'John's sword' }
\end{aligned}
$$

János-nak a kard-ja John-DAT the sword-POSS 'John's sword'

Anaphoric and predicative possessives, on the other hand, feature only -é possessors. 

a. Whose sword is this?
c. *János
John
'John's'
b. János-é
d. *János-nak
John-é
John-DAT
'John's'
'John's'

In other words, the -é possessor is specialized for contexts without an overt possessum, and it is in complementary distribution with unmarked and Dative-marked possessors.

(II) It is possible to think of -é as a suffix that attaches to a morphologically unmarked possessor. The suffix -é, however, cannot attach to a Dative-marked possessor.
a. János-é
John-é
'John's one'
b. *János-nak-é
John-DAT-é
'John's one'

(III) When an -é possessor is modified by a demonstrative, then -é must occur on the demonstrative, too. ${ }^{6}$

$$
\begin{aligned}
& \text { ez-*(é) a fiú-é } \\
& \text { this-é the boy-é } \\
& \text { 'this boy's one' }
\end{aligned}
$$

Demonstratives exhibit similar concord for number, case, and case-like postpositions (i.e. postpositions that take a morphologically unmarked complement). ${ }^{7}$
a. ez-ek a csont-ok
this-PL the bone-PL
'these bones'
b. ez-t a csont-ot
this-ACC the bone-ACC
'this bone'
c. ez alatt a ház alatt
this under the house under
'under this house'

\footnotetext{
${ }^{6}$ Note that the interpretation of (41) is 'this boy's one', not 'the boy's this one'. In other words, the demonstrative modifies the possessor rather than the anaphoric possessum.

${ }^{7}$ Case-assigning postpositions, on the other hand, take an oblique marked complement and do not participate in demonstrative concord.

(i) ez-zel (*szemben) a ház-zal szemben this-INS opposite the house-INS opposite 'opposite to this house'
} 
Kenesei (1992), É. Kiss (2002), Asbury (2005, 2008), Dékány (2011), and Hegedûs (2013) argue that case markers and case-like postpositions instantiate the same category, and they only differ in the degree of phonological integration into the complement. I will follow this line of thinking here and take case-like postpositions to be morphologically free case-markers. The analysis of $-\dot{e}$, then, has to account for why the language treats $-\dot{e}$ on a par with number and case.

\subsection{The anaphoric possessor}

(IV) Non-anaphoric possessums bear two suffixes obligatorily: the possessedness marker -ja/-jel-a/-e, and a case marker (but the Nominative has no phonological realization).

$$
\begin{aligned}
& \text { János csont-*(ja) } \\
& \text { John bone-POSS.NOM } \\
& \text { 'John's bone' }
\end{aligned}
$$

Two further suffixes may also appear under the right conditions: the plural marker if the possessum is non-singular, and the possessive agreement cross-referencing the $\phi$-features of the possessor if the possessor is a pronoun.

$$
\begin{aligned}
& \text { a ti kard-ja-i-tok-at } \\
& \text { the you(pl) sword-POSS-PL-2PL-ACC } \\
& \text { 'your swords' }
\end{aligned}
$$

Anaphoric possessives admit these suffixes except for the possessedness marker -ja/$j e /-a /-e$, which is obligatorily absent (45).
a. *a ti-é-ja-i-tok-at the you-é-POSS-PL-2PL-ACC 'your ones'
b. a ti-é-i-tek-et the you-é-PL-2PL-ACC 'your ones'

Since -é possessors only occur in anaphoric and predicative possessives (46), and the possessedness marker cannot appear in these constructions, -é possessors and the possessedness marker $-j a /-j e /-a /-e$ are in complementary distribution.

$$
\begin{aligned}
& \text { *János-é csont-ja } \\
& \text { John-é bone-POSS } \\
& \text { 'John's bone' }
\end{aligned}
$$

(V) The anaphoric possessum rejects a wide range of nominal modifiers: adjectives, classifiers, numerals, participial clauses, and demonstratives cause ungrammaticality in anaphoric possessives. 
*a fiú-é üreges

the boy-é hollow

'the boy's hollow one, 8

adjective

a fiú-é darab

the boy-é CL

'the boy's (one)'

classifier

*a fiú-é két

the boy-é two

'the boy's two ones'

numeral

*a fiú-é tegnap talál-t

the boy-é yesterday find-PRT

'the boy's one that was found yesterday'

participial clause

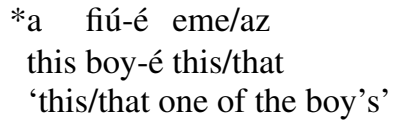

demonstrative

Of these inadmissible nominal modifiers, numerals and participial clauses are phrasal, the status of adjectives as phrases or heads is debated in the literature (I take them to be phrases sitting in specifier positions), demonstratives split into phrasal and head demonstratives (see below), and classifiers correspond to heads. The restriction on nominal modifiers thus affects both heads and specifiers in the extended nominal hierarchy.

What adjectives, classifiers, numerals, participial clauses, and demonstratives have in common with each other as well as with the possessedness suffix $-j a /-j e /-a /-e$ is that they are all merged below the Poss 2 head. The possessedness suffix is the exponent of the Poss head. Adjectives and classifiers are merged between PossP and NumP, and numerals are merged in the specifier of NumP. Participial clauses can be merged either below NumP, in the same zone as adjectives, or between NumP and Poss2P. The relative order of these noun modifiers is shown in (52); adjectives, classifiers, numerals, and participial clauses all follow the unmarked possessor én sitting in spec, Poss2P.

az én (tegnap talál-t) két darab (tegnap talál-t) üreges csont-om the I yesterday find-PRT two CL yesterday find-PRT hollow bone-1SG 'my two bones that were found yesterday'

For the sake of explicitness, I am going to assume that adjectives and participial clauses are introduced in specifiers of dedicated functional projections (but nothing crucial hinges on this, and the shape of the arguments would remain the same even if they were taken to be adjuncts). On the basis of the discussion in Sect. 2 and the linear order in (52), we arrive at the partial DP-hierarchy in (53). ${ }^{9}$

\footnotetext{
${ }^{8}$ This example is grammatical on the irrelevant predicative reading 'The boy's one is hollow'.

${ }^{9}$ Discussion of the relative order of adjectives and classifiers would divert us into a very different domain of data, and I will not attempt it here. The interested reader is referred to Muromatsu (2003), Truswell
} 


$$
\text { DP }>\text { Poss2P }>\text { PrtcP }>\text { NumP }>\text { ClP/PrtcP/AP }>\text { PossP }>\text { NP }
$$

Demonstratives in Hungarian come in two types. Non-inflecting demonstratives ( $e$ 'this', eme 'this', ezen 'this', ama 'that' and azon 'that') represent a somewhat archaic, elevated or poetic register. They do not show agreement with the noun, and they correspond to heads in the functional hierarchy (Szabolcsi 1994; Dékány 2011). These demonstratives follow the definite article. ${ }^{10}$

a [tegnap talál-t] eme hét üreges csont-ot the yesterday find-PRT this seven hollow bone-ACC 'these seven hollow bones found yesterday'

I will call the phrase that hosts non-inflecting demonstratives DemP. ${ }^{11}$ As shown by (55), non-inflecting demonstratives are also merged below Poss2P: DemP is between Poss2P (hosting unmarked possessors) and NumP (hosting numerals) in the functional hierarchy, and it can be either preceded or followed by participial clauses.

az én (tegnap talál-t) eme (tegnap talál-t) két üreges csont-om the I yesterday find-PRT this yesterday find-PRT two hollow bone-1SG 'these two hollow bones of mine that were found yesterday'

$$
\begin{aligned}
& \text { DP }>\text { Poss } 2 \text { P }>\text { PrtcP }>\text { DemP }>\text { PrtcP }>\text { NumP }>\text { ClP/PrtcP/AP }>\text { PossP }> \\
& \text { NP }
\end{aligned}
$$

Inflecting demonstratives, on the other hand, show $\phi$-feature agreement with the noun, they obligatorily co-occur with the definite article, and immediately precede it (57). They are phrasal (pronominal) in nature.

$$
\begin{aligned}
& \text { ez-ek-et az üreges csont-ok-at } \\
& \text { this-PL-ACC the hollow bone-PL-ACC } \\
& \text { 'these hollow bones' }
\end{aligned}
$$

The strict adjacency of the inflecting demonstrative and the definite article has led to the consensus view that the surface position of these demonstratives is the specifier of DP (Kenesei 1992; Bartos 1999; É. Kiss 2002).

(2004), Svenonius (2008) for discussion and to Dékány (2011) and Csirmaz and Dékány (2014) for an analysis of the Hungarian facts.

${ }^{10}$ However, as shown in (i), they cannot be contiguous to the definite article: the linear order becomes visible only if a possessor or a participial clause intervenes between them, cf. Szabolcsi (1994). This detail is orthogonal to the topic of anaphoric possessives.

(i) (*az) eme hét üreges csont-ot

the this seven hollow bone-ACC

'these seven hollow bones'

\footnotetext{
${ }^{11}$ A reviewer asks what the relationship is between DemP and Szabolcsi's (1994) DetP. DemP, as used here, is a functional head dedicated to demonstratives. Szabolcsi's DetP, on the other hand, is a functional head that "determines both the quantification and the definiteness of the noun phrase" (p. 219). In addition to non-inflecting demonstratives, it also houses "determiners" in general: minden 'all', melyik 'which', valamennyi 'each', bármelyik 'either', semelyik 'neither', and possibly a few others.
} 
I argue elsewhere (Dékány 2011) that the specifier of DP is a derived position for inflecting demonstratives, though, and their base position is the specifier of DemP. In other words, the two kinds of demonstratives are base-generated in the same functional projection, DemP, which means that inflecting demonstratives, too, are merged below Poss2P. This approach is in line with much recent work that suggests that demonstratives are generated below DP and reach the left edge of the nominal phrase by movement. A list of earlier work in this vein includes Bernstein (1997, 2001), Panagiotidis (2000), Brugè (2002), Alexiadou et al. (2007), and Guardiano (2009).

To summarize, every nominal modifier that is excluded from Hungarian anaphoric possessives is merged below Poss2P. But is it the case that all NP-modifiers merged below Poss $2 \mathrm{P}$ are excluded? In other words, are there any NP-modifiers that are merged below Poss $2 \mathrm{P}$ and can occur in anaphoric possessives? There are two such items. The first is the possessor itself: it is merged in spec, PossP. The second item is the plural marker, which sits in the Num head. (59) summarizes the DP-hierarchy and shows in bold those projections/positions that mustn't be filled in anaphoric possessives. The bolded positions do not form a contiguous sequence in the functional sequence. The challenge for the analysis of -é possessives here is to find out in what sense the excluded items form a natural class, or alternatively, in what sense the allowed NP-modifiers form a natural class (then the excluded modifiers constitute the elsewhere case).

$$
\begin{aligned}
& \text { DP }>\text { Poss } 2 \text { P }>\text { PrtcP }>\text { DemP }>\text { PrtcP }>\text { spec, NumP }>\mathrm{Num}^{0}>\text { CIP/PrtcP } / \\
& \text { AP }>\text { spec, PossP }>\text { Poss }^{0}>\text { NP }
\end{aligned}
$$

This concludes my survey of the five key distributional properties of -é. In the next section I turn to previous analyses of -é possessives.

\section{Previous analyses}

There are three generative analyses of -é possessives. They all agree that anaphoric possessives in Hungarian involve a pro-form (this view is also shared by the present paper). They hold different opinions, however, on the syntactic function and position of the -é morpheme. Laczkó (2007) suggests that -é is the pro-form itself. Bartos (1999, Chap. 2.2) and Bartos (2000) propose that the pro element is phonologically zero, and - $e$ is a flavour of the Poss head. Finally, Bartos (2001) argues that the proform is phonologically zero, while $-e ́$ sits in the Poss head and has case-like properties. Specifically, $-e ́$ is the Genitive case marker in Hungarian. I will discuss these proposals in turn, pointing out how they do or do not account for the five key properties discussed in the previous section.

\subsection{The suffix -é as the pro element}

Laczkó (2007) presents an LFG analysis of Hungarian anaphoric possessives. In his view -é possessives do not involve a zero element; the suffix -é is the pro-form itself, 
standing in for the possessed noun plus possessedness suffix (-ja/-je/-a/-e) complex (p. 334: "an LFG-style "pro" element ... the functional and semantic head of the whole nominal expression ... most straightforwardly analyzable as a "pro possessive noun head" element"). ${ }^{12}$

This analysis readily explains why -é only occurs in anaphoric possessives (it is the anaphoric element itself), and it captures the complementary distribution between $-e ́$ and the possessedness suffix -ja/-je/-a/-e (-é replaces a chunk of structure that contains $-j a /-j e /-a /-e)$. That the suffix $-e$ is incompatible with adjectives, numerals, participles, and demonstratives (60a) falls out because $-e$ is a suffix on the possessor and hence does not have its own node.
a. *János-é hét zöld, *János hét zöld-é
John-é seven green, John seven green-é 'John's seven green ones'
b. John's seven green ones / these seven green ones of John's

The other two properties of -é constructions, however, appear to pose a problem for the analysis. The first potential problem is the fact that Dative possessors are incompatible with -é. In ordinary possessive constructions the possessor may be either morphologically unmarked or Dative-marked. In Laczkó's analysis -é encodes the N-pro possessum, and it phonologically leans onto the unmarked possessor that precedes it. It is unclear why this would have an effect on the case-marking of the possessor, such that only unmarked possessors are possible and Dative-marked ones are no longer admissible.

The second potential problem is the fact that -é is involved in demonstrative concord on demonstratives modifying the possessor.

$$
\begin{aligned}
& \text { ez-é a javaslat-é } \\
& \text { that-é the proposal-é } \\
& \text { 'the one/that of this proposal' }
\end{aligned}
$$

Concord spreads the modifiee's $\phi$-features (its person, number, and gender) and its case features onto modifiers. Hungarian demonstrative concord spreads the noun's number and case features onto the demonstrative (Hungarian has no gender, and person does not come into play because demonstratives may only modify third person nouns). In Laczkó's analysis -é is the pro-form possessum. Thus this analysis has to assume that in (61) demonstrative concord operates in a highly exceptional way: it spreads not just $\phi$-features, but the whole modifiee, i.e. the whole -é pronoun. Such wholesale spreading of nouns (or pronouns) onto demonstratives, however, is unattested in the language.

In addition to the two above-mentioned potential problems, the analysis also faces a challenge when we consider what sort of phrases can occupy the possessor position in -é possessives. In Laczkó's analysis -é "stands for the possessed noun" (p. 327), and the possessor that precedes it is an ordinary morphologically unmarked possessor.

\footnotetext{
${ }^{12}$ The same idea is also expressed in Lotz's (1968) descriptive approach: "-é is substituted for the stem portion of the head of the nominal phrase; it points to this segment—and to the attributes, if any" (p. 634).
} 


$$
\text { János }_{(\text {unmarked possessor) }} \text {-é (possessum) }
$$

It is therefore expected that the possessor in -é possessives patterns like ordinary unmarked possessors in all respects. This is not the case, however. Demonstrative pronouns, for instance, cannot be ordinary unmarked possessors (63); they must take Dative case in the possessor position (64). In anaphoric possessives, on the other hand, demonstratives do, and in fact, have to occur without Dative case; compare (65) and (66). If the -é of (65) stands in for the illat-a of (63), as in Laczkó's analysis, then it is unclear why the morphologically unmarked demonstrative can occur in (65) but not (63).

*Ez illat-a friss.

this smell-POSS fresh

'The smell of this one is fresh.'

Ez-é friss.

this-é fresh

'This one's (one) is fresh.'

Furthermore, ordinary unmarked possessors can express a descriptive possessive relationship (a the city of Paris, the festival of Easter type of possessive relationship), see $(67 \mathrm{a})$, but this is not possible for Dative possessors or the possessors in the $-e$ construction.

\footnotetext{
a. húsvét ünnep-e tavasszal volt, karácsony ünnep-e

Easter festival-POSS spring.INS was Christmas festival-POSS

december-ben lesz

December-in will.be

'The festival of Easter was in the spring, the festival of Christmas will be in December.'

b. *húsvét-nak az ünnep-e

Easter-DAT the festival-POSS

'the festival of Easter'

c. *?húsvét ünnep-e tavasszal volt, karácsony-é december-ben

Easter festival-POSS spring.INS was Christmas-é December-in

lesz

will.be
}

If the possessors in -é possessives were ordinary unmarked possessors, as in Laczkó's analysis, then (67c) would be expected to receive the same judgment as (67a), contrary to fact.

\subsection{The suffix -é as the Poss head}

Bartos (1999, Chap. 2.2) and Bartos (2000) argue that -é lexicalizes the Poss head: it is an intransitive Poss variant (68), or alternatively it takes a phonologically zero anaphoric NP complement (69). Since the possessedness suffix -ja/-je/-a/-e and -é compete for the same position, the Poss head, they are in complementary distribution. 


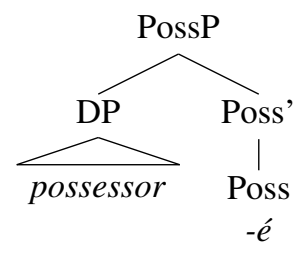

(69)

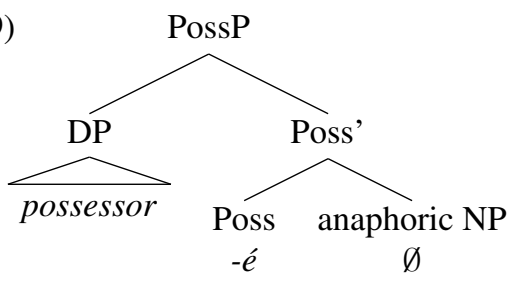

Bartos argues that an affix in the Poss head is suffixed to its complement, the possessum, if it can. A phonologically zero or missing complement, however, is unable to support suffixes. So in order to fulfill its requirement for an overt host, the suffix -é cliticizes onto the possessor as a last resort.

This analysis accounts for why -é only occurs in anaphoric possessives (this variety of Poss subcategorizes for the anaphoric NP complement), and it also explains why there is no possessedness suffix -ja/-je/-a/-e in anaphoric possessives (it is -é that fills the Poss head in this case). However, it falls short of explaining the incompatibility between - $e$ and nominal modifiers. Consider the nominal functional sequence, repeated below for the reader's convenience.

$$
\begin{aligned}
& \text { dative possessor }>\text { DP }>\text { Poss } 2 \mathrm{P}>\text { PrtcP }>\text { DemP }>\text { NumP }>\text { AP }>\text { PossP }> \\
& \text { NP }
\end{aligned}
$$

Possessors with -é are in complementary distribution not only with NP and -ja/-je/ $-a /-e$, but also with adjectives, classifiers, numerals, demonstratives, and participial clauses. These modifiers are all merged above PossP, so their appearance should not be affected by what lexicalizes the Poss head and the head noun.

This analysis also does not account for the fact that the possessedness suffix $-j a /-j e /-a /-e$ and $-e$ have a different distribution with regard to demonstrative concord. Recall that -é obligatorily takes part in demonstrative conord: if the possessor bears this suffix, so must its demonstrative modifier (71). The possessedness suffix, however, cannot appear on the demonstrative modifier of the possessor (72), whether the possessor is unmarked or bears Dative case (note that changing the order of the possessedness suffix and the dative suffix on the demonstrative of (72b) would not affect the ungrammaticality).

$$
\begin{aligned}
& \text { ez-é a fiú-é } \\
& \text { this-é the boy-é } \\
& \text { 'this boy's one' }
\end{aligned}
$$
a. *[ez-(j)e a fiú] csont-ja
this-POSS the boy bone-POSS
'this boy's bone'
b. *[ennek-je a fiú-nak] a csont-ja this.DAT-POSS the boy-DAT the bone-POSS 'this boy's bone'

If both -ja/-je/-a/-e and -é spell out the Poss head, the source of this asymmetry remains a mystery. Furthermore, it also remains unclear why we never get $-e$ on a Dative possessor. It should be possible to merge a Dative posssessor in anaphoric 
possessives, and the Poss exponent -é could lean onto the Dative possessor for phonological support, but this does not materialize.

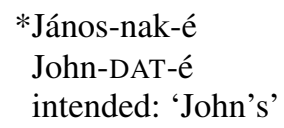

Finally, in this analysis, just as in Laczkó's, the possessor in -é possessives is an ordinary morphologically unmarked possessor, therefore it is predicted to have the same properties as unmarked possessors. We have seen in Sect. 4.1, however, that this is not the case: demonstratives cannot be unmarked possessors but they do occur in -é possessives, and unmarked possessors can be descriptive possessors, but the possessors of the $-\dot{e}$ construction cannot.

\subsection{The suffix - $e$ as the Genitive case}

Bartos (2001) builds on the analysis in Bartos $(1999,2000)$ and takes the analysis one step further. Recall that in his previous analysis, anaphoric possessives involve a phonologically zero pro-form in the position of the possessum, and -é is in the Poss head. This leaves three properties of -é possessives unaccounted for: the involvement of - $e$ in demonstrative concord, the lack of NP-modifiers, and the lack of Dative possessors in anaphoric possessives. Bartos (2001) argues that the demonstrative concord facts can be given a straightforward account if -é is taken to be a kind of case marker: the Genitive case of Hungarian.

Analyzing -é as a case marker has a number of immediate payoffs. Firstly, it allows us to eliminate a curious gap in the inventory of Hungarian cases. It is a matter of debate in the literature which Hungarian suffixes are genuine case markers and which ones are not, but even according to the strictest count, there are 17 case markers (this includes the morphologically zero Nominative, cf. Antal 1961; Kornai 1986). In spite of this impressive number of cases, Hungarian does not appear to have a separate Genitive case (recall that garden variety possessors are either unmarked or Dative-marked). If - $e$ is the Genitive case marker, the gap in the paradigm can be eliminated.

Secondly, taking -é to be the Genitive case allows a natural account of the demonstrative concord facts. It is only -é, case markers, and the plural marker that demonstratives show concord for. If the suffix -e is the Genitive case, then the picture is more uniform: demonstratives show concord for number and case.

Thirdly, this analysis also meshes well with the suffix order of possessors. Possessors can be themselves possessed and plural (74).
a. a diák-ja-i-m
csont-ja
the student-POSS-PL-1SG bone-POSS
'my students' bone'
b. a diák-ja-i-m-nak a csont-ja
the student-POSS-PL-1SG-DAT the bone-POSS
'my students' bone'


When such a possessor bears the -é marker, -é appears in the linear sequence of nominal suffixes exactly where case markers do: on the right edge, following the plural and the possessive agreement suffix (75). ${ }^{13}$

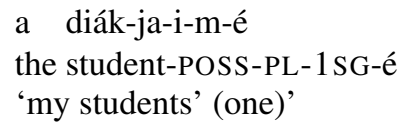

To summarize, this analysis makes sense of the otherwise mysterious demonstrative agreement facts (-é is a case marker), and it explains why -é does not co-occur with Dative possessors (a possessor may be assigned either Dative or Genitive case but not both). It also accounts for the fact that -é does not co-occur with the possessedness marker -ja/-je/-a/-e (they compete for the Poss position), and it explains why $-e ́$ only occurs in anaphoric possessives $(-e ́$ selects for a phonologically zero anaphoric NP).

However, the issue of why the anaphoric possessum cannot have overt modifiers is not explained (or even raised) in the discussion, and there are also conceptual problems with analyzing -é as a case-type Poss head. Firstly, in an approach that takes case to project a syntactic phrase, as in Bartos' account and the present paper, the case phrase tops off the nominal projection rather than appearing somewhere in the middle of it (cf. Bittner and Hale 1996 or indeed any analysis employing a KP). The function of case is to embed the noun (in this case, the possessor) in the syntactic representation (the containing $\mathrm{vP}, \mathrm{PP}$, or as in this case, DP). It is not clear how this could happen with case sitting in the middle of a nominal sequence rather than on the syntactic boundary between the embedding category (here the possessum's projection) and the embedded category (here the possessor's projection). ${ }^{14}$ Secondly, even if case could be in the middle of the nominal hierarchy, it would certainly have to be within the projection of the noun phrase it belongs to. In the analysis of possessives, this means that the case of the possessor must be within the nominal projection of the possessor itself, and it cannot possibly be in the nominal projection of the possessum

\footnotetext{
${ }^{13}$ As we have already seen, the suffix -é can also be followed by a plural suffix, a possessive agreement marker, and a case marker. Any suffix following -é is a suffix of the anaphoric, unpronounced possessum.
}

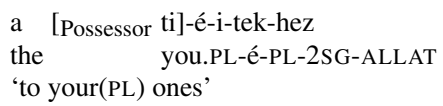

(ii)

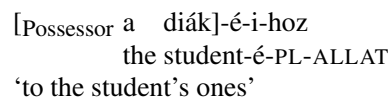

On the other hand, any suffix that precedes $-\dot{e}$ is a suffix of the possessor, cf. (75). When both the possessor and the possessum are plural, then the plural appears twice: once in a position preceding and once in a position following -é. These positions correlate with scope: the one preceding -é scopes over the possessor, while the one following -é scopes over the possessum.

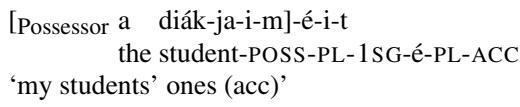

${ }^{14}$ In an approach that takes case not to project a syntactic phrase, case is either a feature on $\mathrm{N}$ or on $\mathrm{D}$, but again, not a feature on a functional category in between. 
(which is the case if -é is the Genitive case of the possessor as well as the Poss head of the possessum, as in Bartos 2001).

It is possible to keep the advantages of the Genitive analysis and avoid the above mentioned conceptual problems if -é is analysed as a pure Genitive case marker, lexicalizing the $\mathrm{K}$ head within the projection of the possessor. Bartos briefly mentions this as a possibility (p. 35). In the next sections I will argue extensively that this is indeed the right analysis of the -é suffix, and will explore the predictions and consequences of this approach.

\section{The morpheme $-e$ is the Genitive case}

Bartos (2001) made a strong case that the suffix - $e$ is the Genitive case; as far as I can tell, the demonstrative concord facts do not follow naturally in any other way. In this section I present two major and four minor but suggestive pieces of evidence supporting this view.

\subsection{Syntactic evidence}

\subsubsection{Evidence from demonstrative modification}

As already discussed above, Hungarian has two well-known possessor types: morphologically unmarked possessors and Dative possessors.
a. a tanár csont-ja
the teacher bone-POSS
'the teacher's bone'
b. a tanár-nak a csont-ja
the teacher-DAT the bone-POSS
'the teacher's bone'

As the Hungarian Nominative case is phonologically zero, unmarked possessors may be analysed either as Nominative or as caseless DPs. Bartos (2001) and É. Kiss (2002) argue that morphologically unmarked possessors in Hungarian are caseless rather than Nominative. The motivation for this position comes from the distribution of demonstratives in possessive constructions.

Bare inflecting demonstratives (i.e. inflecting demonstratives not bearing plural marking or an overt case suffix) are fully grammatical in subject position in both pronominal (77a) and adnominal use (77b).
a. Ez tágas.
this spacious
'This is spacious.'
b. Ez a ház tágas. this the house spacious 'This house spacious.'

In the possessor position, however, they cannot be bare in either pronominal (78a) or adnominal use (79a); they have to bear Dative marking instead. (This contrasts with Referential expressions, which can serve as either unmarked or Dative possessors, cf. (76).) 

a. *Ez ház-a tágas.
this house-POSs spacious
'The house of this one is spacious.'
b. Ennek a ház-a tágas.
this.DAT the house-POSS spacious
'The house of this one is spacious.'
a. *[Ez a tanár $]$ ház-a tágas.
this the teacher house-Poss spacious
'This teacher's house is spacious.'
b. [Ennek a tanár-nak] a ház-a tágas.
this.DAT the teacher-DAT the house-POSS spacious
'This teacher's house is spacious.'

Why is it the case that inflecting demonstratives can appear in bare form in (77a) and (77b) but produce ungrammaticality in (78a) and (79a)? Bartos (2001) and É. Kiss (2002) suggest that this surprising idiosyncrasy immediately becomes understandable if demonstratives require case marking but unmarked possessors do not have case (cf. also É. Kiss 1998:85). Then inflecting demonstratives get Nominative case as subjects, Dative case as possessors, and (78b) and (79b) are out because the case requirement of the demonstrative is not fulfilled. This analysis provides a principled account of the contrast between (77), (78), and (79), and I will take it on board here. (This pattern, in fact, has no alternative explanation in the literature.) ${ }^{15,16}$

\footnotetext{
${ }^{15}$ A reviewer asks why other nominals can get away without case marking as unmarked possessors. I assume with Den Dikken $(1999,2006,2007)$ that the possessor and the possessum are in a predicative relationship, with the possessum being the subject of predication and the possessor being the predicate (see also Larson and Cho 2003). Predicate noun phrases do not need case, hence possessors can escape the Case Filter. Of course, this is not to say that specific languages cannot require predicates in certain positions to have case, $\mathrm{cf}$. (i).
}

Therefore I do not exclude the possibility that specific languages require their possessors to have case (this obviously materializes in a lot of languages). What I suggest is that in the absence of a language-specific requirement to the contrary, possessors escape the Case Filter by virtue of being predicates.

${ }^{16}$ As pointed out in Bartos (2001), certain speakers allow the plural version of (78a), but even these speakers reject the plural version of (79a). It is not clear at this point whether the speaker variation on this point stems from dialectal or other factors.
a. \%Ez-ek ház-a tágas. this-PL house-POSS spacious 'The house of these is spacious.'
b. *[Ez-ek a tanár-ok] ház-a tágas. this-PL the teacher-PL house-POSS spacious 'These teachers' house is spacious.'


Crucially for us, -é possessors can be modified by demonstratives (80), and demonstratives with -é can serve as pronominal possessors (81).

$$
\begin{aligned}
& \text { [Ez-é a fiú-é] tágas. } \\
& \text { this-é the boy-é spacious } \\
& \text { 'This boy’s (one) is spacious.' }
\end{aligned}
$$

$$
\begin{aligned}
& \text { Ez-é tágas. } \\
& \text { this-é spacious } \\
& \text { 'This one's (one) is spacious.' }
\end{aligned}
$$

Given that (80) and (81) are grammatical, the demonstratives in them must have case. Under the most reasonable interpretation of the data, that case is -é itself, as once $-e ́$ is dropped, the examples become ungrammatical (see (78a) and (79a)). And if $-e ́$ is a case, it must be the Genitive, as this case is closely tied to possession and it is missing from the inventory of Hungarian cases. (80) and (81) thus support the Genitive analysis of -é.

Before we move on to the other arguments, I need to clarify the status of the nominal suffixes that may follow -é. We have seen that $-e ́$ can be followed by the plural marker of the possessum, the possessive agreement on the possessum, and the case marker of the possessum. We have established that these suffixes are in the extended projection of the covert possessum.

$$
\begin{aligned}
& \text { a ti-é-i-tek-et } \\
& \text { the you-é-PL-2SG-ACC } \\
& \text { 'your(pl) ones' }
\end{aligned}
$$

Above I argued that the suffix - $e$ is the Genitive case of the possessor. But if this is so, why is it not in the final morphotactical position? How is the suffix order of examples like (82) derived, with the suffixes of the anaphoric, phonologically zero possessum cliticized to the possessor's case suffix? The answer lies in the properties of nominal affix stranding in Hungarian. Unpronounced nominal heads leave behind their suffixes, and these suffixes lean onto the last overt element in the noun phrase for phonological support (see Lipták and Saab 2014, to appear). Consider the following examples of nominal ellipsis:
a. a nagy piros almá-k-at
the big red apple-PL-ACC
'the big red apples'
b. a nagy piros-ak-at
the big red-PL-ACC
'the big red ones'
c. a nagy-ok-at
the big-PL-ACC
'the big ones'

It is this phenomenon that we can see in (82), too. Recall that in anaphoric possessives the overt modification of the unpronounced possessum is heavily restricted: the only phrasal modifier that can appear overtly is the possessor itself. Therefore the

Bartos (2001) sets (ia) aside for further research. The analysis of this variation is still a standing issue, on which I have nothing interesting to contribute. 
stranded suffixes of the possessum will lean on this element for phonological support. The structure of (82) is thus (84), with pro marking the place of the unpronounced possessum, the head of the whole construction.

$$
\text { [Possessum a [Possessor ti-é]-pro-i-tek-et] }
$$

Observe the same process in Huallaga Quechua and Udmurt (Finno-Ugric), where after NP-ellipsis the case marker of the possessum is supported by the Genitive marked possessor. (The Udmurt object of comparison bears Ablative case, this is the equivalent of the comparative than in English.)

Hwan-pa wasi-n-ta rika-a.

John-GEN house-3SG-ACC see-1SG

'I see John's house.' (Blake 2001:103; ex. 28.) Huallaga Quechua

(86) Hwan-pa-ta rika-a.

John-GEN-ACC see-1SG

'I see John's (house).' (Blake 2001:103; ex. 29.)

$$
\begin{aligned}
& \text { kdmurt-län veś-ez'-kin-län-leś badžin } \\
& \text { udmurt-GEN prayer-POSS.3SG every-who-GEN-ABL big } \\
& \text { 'The prayer of the udmurt is bigger than that of everyone else.' } \\
& \text { (Papp 1955:293.) }
\end{aligned}
$$

Udmurt

\subsubsection{Evidence from the distribution of interrogative and relative pronouns}

The distribution of indefinite pronominal $w h$ - possessors and relative pronominal possessors provides support for the analysis of $-e ́$ as the Genitive case in the same way as the distribution of demonstratives does. Referential expressions in Hungarian may serve as either unmarked or Dative possessors (cf. the examples in the foregoing discussion), but the indefinite interrogative pronouns $k i$ 'who', $m i$ 'what', and relative pronouns cannot be unmarked possessors (Szabolcsi 1983; Szabolcsi and Laczkó 1992).

a. * Ki csont-ja van itt?

who bone-POSs be.3SG here

'Whose bone is here?'

b. *Mi csont-ja van itt? what bone-POSS be.3SG here

'The bone of what is here?'

c. *az a fiú, aki csont-ja

that the boy rel.pron bone-POSS

'the boy whose bone'

(89) a. Ki-nek a csont-ja van itt?

who-DAT the bone-POSS be.3SG here

'Whose bone is here?'

b. Mi-nek a csont-ja van itt?

what-DAT the bone-POSs be.3SG here

'The bone of what is here?' 


\section{c. az a fiú, aki-nek a csont-ja \\ that the boy rel.pron-DAT the bone-POSS \\ 'the boy whose bone'}

Morphologically unmarked $k i$ 'who', $m i$ 'what', and relative pronouns are, however, perfectly grammatical in the subject position.
a. $\mathrm{Ki}$ van itt?
who be.3SG here
'Who is here?'
b. Mi van itt?
what be.3SG here
'What is here?'
c. Aki jön, az csoki-t kap. rel.pron come.3SG that chocolate-ACC get.3SG
'Those who come get chocolate.'

As far as I am aware, the reason why these pronouns cannot be unmarked possessors has not been addressed in the literature. It is difficult to miss, however, that this pattern is exactly the same as the one we have seen for demonstratives. Therefore the null hypothesis is that its explanation, too, should proceed along the same lines. This is indeed what I suggest: I submit that the interrogative $k i$ 'who', mi 'what', and relative pronouns require case just like inflecting demonstratives do. Thus (89) and (90) are grammatical because the pronouns get case in them (Dative and Nominative respectively), and (88) is out because the pronouns are in a caseless position. ${ }^{17}$

\footnotetext{
universal quantifier minden).
a. vala-ki, minden-ki some-who every-who 'somebody, everybody'
b. vala-mi, *minden-mi some-what every-what 'something, everything'
c. minden every 'everything'

${ }^{17}$ An anonymous reviewer points out that $k i$ 'who' can combine with the existential quantifier vala and the universal quantifier minden, and $m i$ 'what' can combine with the existential quantifier vala (but not the

These quantified forms, in turn, can serve as unmarked possessors.

$$
\begin{aligned}
& \text { vala-ki/minden-ki ház-a } \\
& \text { some-who/every-who house-Poss } \\
& \text { 'someone's/everyone's house' }
\end{aligned}
$$
b. vala-mi ház-a some-what house-POSS 'something's house'

It is clear that the feature composition of $k i$ 'who', $m i$ 'what' in (88a) and (88b) on the one hand and in (iia) and (iib) on the other hand are different. In (88a) and (88b) we are dealing with genuine interrogative pronouns with a $w h$-feature, while in (iia) and (iib) $k i$ and $m i$ are not interrogative pronouns and concomitantly lack the $w h$-feature. This is consistent with the proposal made above, viz. that it is the indefinite interrogative pronouns what require case, rather than indefinite pronouns in general.

The reviewer also points out that an interrogative pronoun followed by the quantified pronoun is fine as an unmarked possessor. 
In light of this, consider now $k i$ 'who', $m i$ 'what', and relative pronouns as possessors in elliptical noun phrases.
a. Ki-é van itt?
who-é be.3SG here
'Whose one is here?'
b. Mi-é van itt?
what-é be.3SG here
'The one of what is here?'
c. Aki-é a tudás, az-é a hatalom. rel.pron-é the knowledge that-é the power
'Those who have knowledge have power.'

In (91) the pronouns in question are in the same unmarked possessor position as in (88). We can see, however, that once -é-marked, they become acceptable as possessors. This means that the pronouns in (91) are case marked, and under the most natural account of the data this case is -é (otherwise these pronouns would not receive case and thus (91) should be ungrammatical, contrary to fact).

Note that the alternative analyses in which -é spells out the Poss head (Bartos 1999, 2000) or the possessed noun plus possessedness suffix complex (Laczkó 2007) do not show any promise of handling (91). In these analyses -é leans onto a garden variety unmarked possessor for phonological support. However, we have seen that $\mathrm{ki}$ 'who', $\mathrm{mi}$ 'what', and relative pronouns cannot be unmarked possessors, and it does not strike me as very plausible that the phonological hosting of an -é Poss suffix should change that property.

\subsubsection{Evidence from descriptive possessives}

In the foregoing discussion we have seen that certain pronouns cannot be unmarked possessors but they can be Dative or -é marked possessors. Following Bartos (2001) an É. Kiss (2002) I argued that unmarked possessors are caseless, and the pronominals in question need case. The fact that they become acceptable in these positions once they are -é marked leads to the conclusion that -é possessors have case. In this section I turn the argument around and show that possessive relations that can be expressed with an unmarked possessor but not with a Dative possessor also reject -é possessors. On the basis of this fact I will argue that -é possessors cannot be analysed as unmarked possessors that give phonological support to a Poss or pro exponent $-e ́$.

Possessive DPs can express a variety of relations: ownership, kinship, part-whole relationship, attribute, orientation or location, or some vague association (Williams 1981). Here I am interested in descriptive possessives, i.e. the the city of Paris type.

\footnotetext{
(iii) a. ki mindenki ház-a

who every-who house-POSS

'who all's house'
}
b. mi minden csont-ja what everything bone-POss 'what all's bone'

At present, I have no suggestions as to why the judgments of (88) and (iii) are different, and I will set this issue aside. 
In Hungarian this type of possessive construction can only be expressed with an unmarked possessor. ${ }^{18}$
a. Budapest város-a
Budapest city-POSS
'the city of Budapest'
b. húsvét ünnep-e easter festival-POSS
'lit: the festival of Easter'

a. *Budapest-nek a város-a

Budapest-DAT the city-POSS

'the city of Budapest'

b. *húsvét-nak az ünnep-e

easter-DAT the festival-POSS

'lit: the festival of Easter'

Explicit discussion of these data is somewhat rare (though see Chisarik and Payne 2003 for a few remarks), and considerably more investigation of descriptive possessives is needed before we can fully understand the nature of the contrast between (92) and (93). We can, however, even in our current state of knowledge, use the pattern in (92) and (93) to support the Genitive analysis of -é.

Not only do Hungarian descriptive possessives resist Dative possessors, but they do not have an anaphoric -é possessive counterpart either. While (94a) and (95a) are fully grammatical, their anaphoric counterparts with -é are definitely deviant.

a. Budapest város-a metró-t épít-tet, Szeged város-a új

Budapest city-POSS metro-ACC build-CAUS Szeged city-POSS new villamos-ok-at vett.

tram-PL-ACC bought

'The city of Budapest is having a new metro line built, the city of Szeged bought new trams.'

b. ?*Budapest város-a metró-t épít-tet, Szeged-é új

Budapest city-POSS metro-ACC build-CAUS Szeged-é new

villamos-ok-at vett.

tram-PL-ACC bought

(95) a. Húsvét ünnep-e tavasszal volt, karácsony ünnep-e

Easter festival-POSS spring.INS was Christmas festival-POSS

december-ben lesz.

December-in will.be

'The festival of Easter was in the spring, the festival of Christmas will be in December.'

b. *?Húsvét ünnep-e tavasszal volt, karácsony-é december-ben

Easter festival-POSS spring.INS was Christmas-é December-in

lesz.

will.be

\footnotetext{
${ }^{18}$ Note that in English, too, there are two kinds of possessors, but this kind of relationship can only be expressed with an of possessive (the city of Paris) and not with the Saxon genitive (*Paris' city).
} 
This is important for us because it cannot be accommodated within the Poss head or the pro analysis of -é but it is compatible with the Genitive analysis. In both alternative analyses, $-e$ lexicalizes a portion in the lower part of the possessed noun's projection, and it leans onto an ordinary unmarked possessor for phonological support. In this scenario any and all kinds of possessive relationships that can be expressed with an unmarked possessor are predicted to be expressible with an -é possessive, too. Therefore (94b) and (95b) are predicted to be grammatical on a par with (92), contrary to fact. The judgments, however, are compatible with the Genitive analysis, as nothing compels a Genitive marked possessor to be able to encode descriptive possessive relations.

This argument is admittedly not as strong as the previous ones because (94b) and (95b) do not directly follow from the Genitive analysis; they are merely compatible with it. But these examples are incompatible with the alternative analyses, and this offers the hope that once the nature of the descriptive possessive construction is better understood, we will be able to show that (94b) and (95b) actually follow from the Genitive analysis. ${ }^{19}$

\subsubsection{Evidence from demonstrative concord}

We have already seen that the plural suffix and the case marker of a noun also appear on an inflecting demonstrative modifying the noun.

$$
\begin{aligned}
& \text { ez-ek-et a fiú-k-at } \\
& \text { this-PL-ACC the boy-PL-ACC } \\
& \text { 'these boys' }
\end{aligned}
$$

Bartos (1999, Chap. 2.4.4) and Bartos (2000, 704-709) argue that since inflecting demonstratives are pronouns, they are contained in a regular extended nominal projection, KP. Within this KP, the demonstrative sits in the D head, while the plural marking and case marking on the demonstrative are harboured in the Num head and the K head respectively (97). In the adnominal use of demonstratives, the KP in (97) occupies the specifier of the DP projected by the modified noun. The structure of (96) is thus (98).

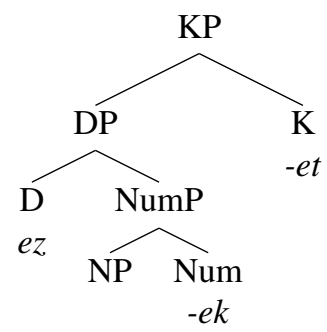

\footnotetext{
${ }^{19}$ In the foregoing discussion we have seen that Hungarian has possessors with specific requirements pertaining to case: inflecting demonstratives, indefinite interrogative pronouns, and relative pronouns require case. We could hypothesize that descriptive possessors show the opposite behaviour: they resist case, and (93) is out because its descriptive possessor is case-marked. Then the ungrammaticality of (94b) and (95b) would actually follow from the Genitive analysis. Exploring this possibility in detail would lead us too far afield into the realm of descriptive possessors, however, and I will not attempt to flesh out this idea here.
} 
(98)

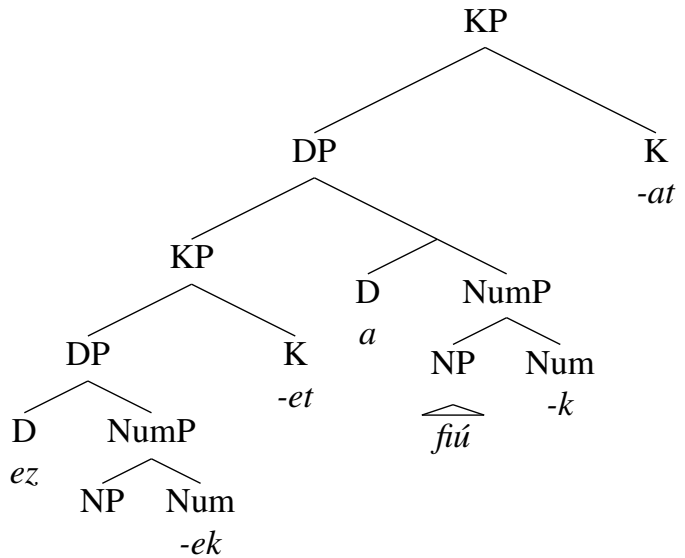

This approach explains why adjectives, numerals, and the definite article do not exhibit concord in Hungarian. Adjectives and numerals are in specifiers so they project XPs, but those XPs are not nominal and therefore do not contain a NumP or KP, while the definite article is a head on the main projection line.

Assuming that the analysis in (97) is on the right track, we can level another argument against the Poss analysis of -é. We have already seen that an -é possessor's demonstrative is also -é marked.

$$
\begin{aligned}
& \text { ez-é a fiú-é } \\
& \text { this-é the boy-é } \\
& \text { 'this boys' (one)' }
\end{aligned}
$$

If it is indeed the case that the suffixes on the demonstrative spell out functional heads within the demonstrative's nominal projection, then we expect them to conform to the Mirror Principle, with suffixes lexicalizing lower heads being closer to the demonstrative. So if -é were the Poss head, then we would expect it to be closer to the demonstrative than the plural marker (because the functional hierarchy is NumP $>$ PossP). This expectation, however, is not borne out: the plural marker is actually flanked by the demonstrative and -é (100).

$$
\begin{aligned}
& \text { ez-ek-é a fiú-k-é } \\
& \text { this-PL-é the boy-PL-é } \\
& \text { 'these boys' (one)' }
\end{aligned}
$$

On the other hand, the suffix order in (100) is just what we would expect under the Genitive analysis of -é (KP > NumP), and therefore can be viewed as corroborating it.

\subsection{Supporting evidence from typology}

\subsubsection{Evidence from Suffixaufnahme}

Further suggestive evidence supporting the proposed analysis comes from the fact that -é possessors exhibit a Suffixaufnahme (a.k.a. double case) effect. In a Suffixaufnahme construction, a noun that is assigned a specific case due to its structural 
position is also inflected for the case (and possibly number) features of the noun it modifies. The Lardil (Tangkic, Macro-Pama-Nyungan), and Awngi (Cushitic, AfroAsiatic) examples below are illustrative.

$$
\begin{aligned}
& \text { Ngada latha karnjin-i marun-ngan-ku maarn-ku } \\
& \text { I spear wallaby-ACC boy-GEN-INSTR spear-INST } \\
& \text { 'I speared the wallaby with the boy's spear.' } \\
& \text { (Richards 2007:2; ex. 3.) } \\
& \text { wolijí-w-des aqí-w-des yón-des } \\
& \text { old-GEN-ABL man-GEN-ABL house-ABL } \\
& \text { 'from the old man's house' } \\
& \text { (Lander 2009:585; ex. 7.) }
\end{aligned}
$$$$
\text { I spear wallaby-ACC boy-GEN-INSTR spear-INSTR }
$$

In (101) the noun marun 'boy' is assigned Genitive case by virtue of being a possessor. In addition, it also shows case concord for the Instrumental case borne by maarn 'spear'. In (102) the Genitive marked noun aqi 'man' modifies the Ablative marked head noun yón 'house', and is infleced for the Ablative case thereof. Note that there is an important difference between the Genitive case and the second case (Instrumental and Ablative) in (101) and (102): the Genitive is assigned to the possessor, while the second case is assigned to the possessum, and it appears on the possessor only as a result of concord.

In (102) the adjectival modifier of aqi 'man' agrees in case with both aqi, the Genitive possessor, and the Ablative possessum. It turns out that Suffixaufnahme on both the possessor and its modifier(s), like in (102), is "an exception rather than the rule" (Plank 1995:93). The most deeply embedded modifiers sometimes link back only to their immediate modifiee, and sometimes they link back only to the head noun of the whole construction. In other words, in some languages the adjective of (102) would be inflected only for Genitive, and in others it would be inflected only for Ablative. Further, in some languages only the most deeply embedded modifier is inflected for double case, intermediate modifiers bear only their own case ending (as if the aqi 'man' of (102) was marked for Genitive only, but the adjective would still bear both Genitive and Ablative case). Observe the following Old Georgian example, in which the number and case marking of the head noun klite 'key' propagate to the most deeply embedded modifier ca-ta 'heavens', but skip the intermediate modifier sasupevel 'kingdom'.

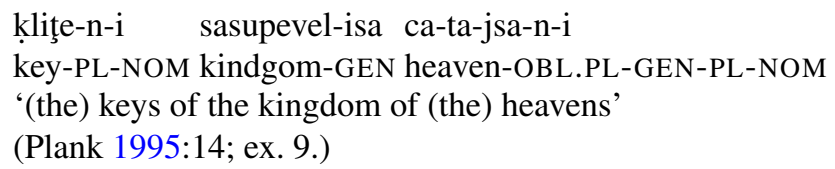

Old Georgian

Hungarian -é possessors exhibit the same type of double case effect as the Old Georgian example above. We have already seen that the demonstrative modifier of an -é possessor shows concord for -é.

$$
\begin{aligned}
& \text { ez-é a fiú-é } \\
& \text { this-é the boy-é } \\
& \text { 'this boy's one' }
\end{aligned}
$$


Our examples so far featured a possessum bearing the phonologically zero Nominative case. Case markers with a non-zero exponent fall into two morpho-phonological classes: Accusative and Superessive ('on') are synthetic (i.e. phonologically well integrated to the stem), while all others are analytic (phonologically less integrated into their stem). ${ }^{20}$ Now if the head noun (the possessum) bears one of the synthetic cases, then the demonstrative modifier of an -é possessor is inflected for double case. That is, if the head noun is marked with Accusative or Superessive case, then these cases must appear on the -é possessor's demonstrative modifier as well.

$$
\begin{aligned}
& \text { [ez-é-t a diák-é]-t } \\
& \text { this-é-ACC the student-é-ACC } \\
& \text { 'this student's one' } \\
& \text { [ez-é-n a diák-é]-n } \\
& \text { this-é-SUP the student-é-SUP } \\
& \text { 'on this student's one' }
\end{aligned}
$$

The possessor itself does not bear double case, it is inflected for -é only. We have seen above that the plural morpheme, the possessive agreement suffix, and the case marker following the possessor's - $e$ are stranded by the 'elided' head noun, and cliticize onto the -é possessor as a last resort. Thus the suffixes following an -é possessor are not concordial in nature. This is indicated by the bracketing in (105) and (106) and the structure in (107). ${ }^{21}$

$$
\text { [Possessor ez-é-t a diák-é]-[Possessum pro-t] }
$$

Non-genitive possessors do not exhibit the demonstrative Suffixaufnahme phenomenon. Unmarked possessors cannot be modified by an inflecting demonstrative in the first place (cf. Sect. 5.1.1). Dative possessors can be modified by an inflecting demonstrative, with the demonstrative agreeing for the possessor's Dative (108). But these demonstratives cannot inflect for double case (109).

$$
\begin{aligned}
& \text { [ennek a tanár-nak] a diák-ja } \\
& \text { this.DAT the teacher-DAT the student-POSS } \\
& \text { 'this teacher's student' } \\
& \text { [ennek- }(* \text { et) a tanár-nak] a diák-já-t } \\
& \text { this.DAT-ACC the teacher-DAT the student-POSS-ACC } \\
& \text { 'this teacher's student' }
\end{aligned}
$$

\footnotetext{
${ }^{20}$ Rebrus (2000) and Bartos (2001) provide a detailed discussion of Hungarian synthetic versus analytical cases. Their arguments and data are summarized in English in Dékány (2011, Chap. 8.9).

${ }^{21}$ Analytical cases do not give rise to a double case construction (i). Interestingly, (i) has no well-formed counterpart: omission of the analytical case from the demonstrative also leads to ungrammaticality (ii).
}
(i) *[ez-é-vel a diák-é]-val this-é-INSTR the student-é-INSTR 'with this student's one'

(ii) * *ez-é a diák-é]-val this-é the student-é-INSTR 'with this student's one' 
The interest of Suffixaufnahme with -é possessors in the present context is that cross-linguistically it is the Genitive that is most prone to double case. Plank (1995:83) writes that modifiers "practicing Suffixaufnahme are prototypically the Genitive, whose prototypical function is to encode nominal attributes, especially those denoting possessors". This claim is also substantiated in Malchukov (2009:636) ("The most widespread pattern of Suffixaufnahme involves the genitive signaling the dependency within the NP in combination with an external case signaling agreement with the head"), and Moravcsik (1995:417) ("In almost all languages, if the internal case involved in Suffixaufnahme is a case other than that of the possessor, the case of the possessor may also be involved in Suffixaufnahme"). This fact thus supports the analysis of $-e ́$ as the Genitive case from yet another angle.

\subsubsection{Evidence from the Blake hierarchy}

Based on considerations specific to Hungarian, Bartos (2001) argues that analyzing $-e ́$ as the Genitive case leads to a neat picture of the inventory of case markers (it is no longer the case that the language has 17 different kinds of cases but curiously no Genitive). It turns out, however, that eliminating this gap from the paradigm is desirable from a wider, typological perspective as well. Blake $(1994,2001)$ observes that languages do not randomly select their case inventory. Cross-linguistically, cases can be arranged on the implicational hierarchy in (110), and "If a language has a case listed on the hierarchy, it will usually have a least one case from each position to the left" (Blake 2001:156).

$$
\text { nom }- \text { acc/erg - gen }- \text { dat }- \text { loc }- \text { abl/inst }- \text { others }
$$

This means that a language that has Dative case will also have Genitive, Accusative (and/or Ergative), and Nominative.

If $-e$ is not the Genitive case, then Hungarian does not conform to this generalization because it has all cases on the hierarchy except for the Genitive. However, if $-e ́$ is the Genitive case indeed, then Hungarian is no longer an exception to Blake's generalization.

\subsection{A prediction concerning predicative possessives}

In the analysis advocated here, the possessor and the suffix -é are in a single nominal functional hierarchy: both are inside the DP of the possessor. In the alternative analyses $-e ́$ lexicalizes the Poss head or the Poss $+\mathrm{N}(\mathrm{P})$ unit, therefore the possessor $+e ́$ string comprises elements from two nominal functional hierarchies: the possessor is trivially in the DP of the possessor, while -é is in the DP of the possessum.

We have seen that $-e ́$ possessors occur only in elliptical and predicative possessive constructions, and conversely, elliptical and predicative possessive constructions always feature an -é possessor. When the -é possessive appears in an argument position, e.g. (111), we can be sure that an empty possessum (an ellipted lexical noun or a pro-form) accompanies the possessor, because the possessum is the argument of the verb. In other words, in examples like (111) the nominal projections of both the possessor and the possessum are present. 
Péter asztal-á-t kicserél-t-ék, János-é-t csak megjavít-ott-ák. Peter table-POSS-ACC replace-PST-3PL John-é-ACC only repair-PST-3PL 'They replaced Peter's desk but only repaired John's.'

This is compatible with both the present approach and the alternative approaches. On the Genitive analysis János-é is in the possessor's nominal phrase, while the possessum's nominal phrase contains either an ellipted regular noun or a phonologically zero pronoun (see Sect. 6 for discussion). In the alternative approaches, János is in the nominal projection of the possessor, while $-e$ is in the nominal projection of the possessum.

However, the status of at least certain predicative possessives, e.g. (112), and its Hungarian equivalent in (113), remains controversial in the literature.

Anything we find on this land is John's. (Partee and Borschev 2001, ex. 22.)

Bármi, ami-t ez-en a föld-ön talál-unk, János-é. anything what-ACC this-on the land-on find-1PL John-é 'Anything we find on this land is John's.'

It is possible that the possessor of predicative possessives is always accompanied by a possessum; in other words, the nominal projections of both the possessor and the possessum are present in all predicative possessives, too. In this scenario predicative possessives are compatible with both the present approach and the alternative approaches, exactly like -é possessives in argument positions.

However, it is debated in the literature whether this is the right approach to all predicative possessives. Some scholars have argued that at least in certain cases, the nominal projection of the possessum is missing from the structure of predicative possessives, and only the DP of the possessor is present (see Zribi-Hertz 1997; Partee and Borschev 2001, among others). In this scenario, the present approach and the alternative analyses make different predictions. In the Genitive analysis advocated here, both the possessor and the -é suffix are predicted to be present in these structurally deficient possessives as well, since both are inside the nominal phrase of the possessor. In the alternative approaches, on the other hand, these structurally deficient possessives are predicted to feature a bare possessor without the -é suffix, as -é lexicalizes a position in the possessum's DP, now missing from the structure.

As Partee and Borschev (2001) point out, it can be difficult to make convincing arguments as to whether (some) predicative possessives contain a possessum or not. Moreover, the arguments that can be made for one language do not necessarily carry over to another language. In this paper I will not be able to settle the issue of whether Hungarian has such structurally impoverished possessives or not. If the answer is yes, then the different predictions of my approach and the alternatives are clear. These predictions remain to be verified until such time as reliable evidence is uncovered for the structure of Hungarian predicative possessives.

\section{Explaining the restrictions on the anaphoric possessum}

The proposal that the morpheme - $e$ is the Genitive case explains two of the five key properties of -é possessors. First, it becomes immediately obvious why -é is incom- 
patible with Dative possessors. A DP may be assigned only one case; if a possessor has already been assigned Dative case, it will not be assigned Genitive, too, and vice versa. Second, it gives a natural account of why the suffix -é participates in demonstrative concord: all case markers in this language do so. What is missing from a complete analysis of -é possessors at this point is an account of the obligatory lack of the possessedness suffix $-j a /-j e /-a /-e$ and several NP-modifiers of the anaphoric possessum, and an account of why -é possessors are confined to anaphoric possessives. In this section I will work out an explanation of these problems.

\subsection{The restriction on modifiers}

The signature property of anaphoric possessives is that the position of the possessed noun, the head of the whole construction, is not filled by a lexical noun with a fixed referent. Instead, the position of the possessed noun is either phonologically empty, or it is filled by some special vocabulary item (e.g. one in English), and it is interpreted under identity with an antecedent. There has been two major approaches to this state of affairs in the literature: PF-deletion (ellipsis) of the possessum, and employing a (possibly phonologically zero) pro-form in the position of the possessum (see Lobeck 2005 for an overview). ${ }^{22}$

English anaphoric possessives have been analysed in both ways. Jackendoff (1977, 58-60), Déchaine and Wiltschko (2002), and Panagiotidis (2003a), among others, argue that English anaphoric possessives employ a pronoun, and this pronoun is one. For Jackendoff, this pronoun stands in for the $\overline{\mathrm{N}}$ constituent, while for Déchaine and Wiltschko and Panagiotidis it stands in for the N head. Harley (2005), on the other hand, proposes that English anaphoric possessives involve ellipsis (understood as blocking of the normal vocabulary item insertion process). She suggests that terminals "which are exact equivalents of other nodes in an appropriate licensing relation" (p. 74) are marked with a feature [+Id]. Nodes with the [+Id] feature require a special vocabulary item to spell them out. The default vocabulary item for this purpose is the null morpheme $\emptyset$. There is, however, a more specialized $[+\mathrm{Id}]$ vocabulary item, too: one is specific to [+count] $\mathrm{n}^{0}$ nodes bearing the [+Id] feature. The lexical entry of one is more specific than that of $\emptyset$, therefore one appears in the position of count $\mathrm{n}^{0}$ heads and blocks $\emptyset$ from the same context, $\emptyset$ serving as the elsewhere case.

Which analysis is better suited to capture the Hungarian facts? I suggest that the pronominal analysis allows a more complete account of the data than the ellipsis approach. Under the ellipsis approach, we could say that the Poss head has two variants. The plain variety is spelled out as $-j a /-j e /-a /-e$, while the variety marked for ellipsis by the $[+\mathrm{Id}]$ feature is spelled out with $\emptyset$. In this scenario the ellipsis feature of the [+Id] Poss head could be inherited by its nP complement, making both the possessum and the Poss head elliptical on the surface. This would derive that anaphoric possessives lack the -ja/-je/-a/-e possessedness marker and the overt lexical possessum.

However, Hungarian anaphoric possessives also lack overt adjectives, classifiers, numerals, demonstratives, and adnominal participial clauses, all of which are merged above the Poss head.

${ }^{22}$ I use the terms pro-form and pro to mean simply 'pronoun'; not the more specific pro of pro-drop. 


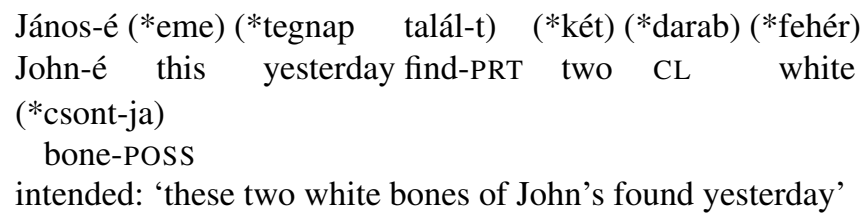

The analysis would have to assume that these modifiers undergo obligatory ellipsis, but this would be very difficult to motivate. It would certainly not be possible to derive this particular case of obligatory ellipsis from a general grammatical principle that has universal validity, as English anaphoric possessives do admit the relevant NP-modifiers (115).
a. these two white ones of John's
b. John's two white ones

Furthermore, there is no Hungarian-internal principle requiring ellipsis of modifiers of anaphoric nouns either: the relevant modifiers are freely admitted in Hungarian anaphoric noun phrases if the noun is not possessed (see also Sect. 1).
a. Kér-em ez-t a két darab fehér-et. want-1SG this-ACC the two CL white-ACC 'I'd like these two white ones.'
b. Kér-em a két tegnap talál-t fehér-et. want-1SG the two yesterday find-PRT white-ACC 'I'd like the two white ones found yesterday.'

As far as I can see, the obligatory ellipsis of the NP modifiers in question remains a stipulation.

On the other hand, if we assume that Hungarian anaphoric possessives feature an anaphoric pronoun, then the presence of the pronoun can be pressed into service to account for the restricted modification. It is well known that in contrast to Referential expressions, pronouns rarely allow modification. That pronouns in Hungarian resist modification is illustrated below with a personal pronoun and a demonstrative pronoun.

$$
\begin{aligned}
& \text { *a tegnap látott/három/okos/ o } \\
& \text { the yesterday seen/three/clever he } \\
& \text { *a tegnap látott/három/okos az/ez } \\
& \text { the yesterday seen/three/clever this/that }
\end{aligned}
$$

I propose that the Hungarian anaphoric possessive construction involves a proform in the position of the possessum (119), and this pro is the reason why the banned NP-modifiers are excluded from the construction.

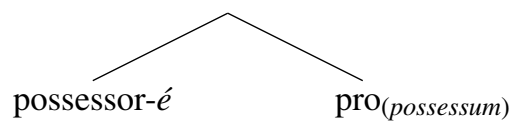

(120) summarizes the functional hierarchy of Hungarian nominal phrases. The projections/positions that mustn't be filled in anaphoric possessives are in bold. 


$$
\begin{aligned}
& \mathrm{KP}>\mathrm{DP}>\text { Poss } 2 \mathrm{P}>\text { PrtcP }>\text { DemP }>\text { PrtcP }>\text { spec, NumP }>\mathrm{Num}^{0}> \\
& \text { CIP/PrtcP/AP }>\text { spec, PossP }>\text { Poss }^{0}>\text { NP }
\end{aligned}
$$

The excluded elements are the possessedness marker, adjectives, classifiers, numerals, demonstratives, and participial relative clauses. The elements that can appear are the definite article, the possessor, the plural marker, the possessive agreement, and the case marker (121).

$$
\begin{aligned}
& \text { az ti-é-i-tek-et } \\
& \text { the you-é-PL-2PL-ACC } \\
& \text { 'your ones' }
\end{aligned}
$$

In Sect. 3 we asked whether the excluded modifiers form a natural class, and the allowed modifiers form their complement set, or the other way around. I suggest that given the presence of the pro-form, the default case for any NP-modifier (be it a head or a specifier) is that it is excluded. The modifiers that can appear are either required by independent factors, or can be shown to be generally compatible with pronouns.

The possessor is required in any possessive construction; if the possessor were not in the structure, we would not be talking about an anaphoric possessive construction to begin with. Pronominal possessors in Hungarian are obligatorily preceded by the definite article $^{23}$ and they obligatorily trigger possessive agreement. So the fact that the definite article and the possessive agreement appear in (121) can be reduced to the general properties of possessive constructions in the language, and do not require further explanation. The fact that the case marker can appear in (121) can also be reduced to an independent factor: non-predicative noun phrases need case, therefore the nominal projection of the possessum has to be closed off by a KP.

The only modifier that can appear in anaphoric possessives but does not seem to be required by independent factors is the plural marker. The appearance of the plural marker is all the more confounding because the general consensus is that the plural sits in the Num head (cf. Bartos 1999, Chap. 2.1; É. Kiss 2000, 2002, Chap. 7, among many others); however, numerals, merged in spec, NumP, are excluded from anaphoric possessives. So apparently number can be expressed in Hungarian anaphoric possessives, but only in a very specific way. What could be the reason why the plural is acceptable but numerals are not? I suggest that this is because the plural is a $\phi$-feature, while numerals do not represent a $\phi$-feature (only the Num head that they merge with does). That pronouns are associated with $\phi$-features is trivial. Furthermore, the plural on Hungarian third person pronouns is always expressed by a suffix.

\footnotetext{
${ }^{23}$ This is an indisputable fact, but I am not aware of any explicit discussion in the literature why this should be the case.
}
(i) *(a) ti könyv-etek the you book-2PL 'your book'

(ii) *(a) ti-é-tek the you-é-2PL 'yours' 


$$
\begin{aligned}
& \text { "o, ő-k } \\
& \text { he/she/it he/she/it-PL } \\
& \text { 'he/she/it, they' }
\end{aligned}
$$

this/that this/that-PL

'this/that, these/those'

(123)

\author{
Ön, Ön-ök \\ you you-PL \\ 'you(sg.polite), you(pl.polite)'
}

The appearance of the plural marker in Hungarian anaphoric possessives is thus possible because this construction involves a pronoun, and pronouns are compatible with affixes expressing $\phi$-features (when the pronoun is not a portmanteau).

To summarize, I argued that the pronoun that is the core of anaphoric possessives in Hungarian excludes NP-modifiers by default, and those modifiers that can appear are either independently known to be compatible with pronouns (the $\phi$-feature lexicalized by the plural), or are independently required on all non-predicative noun phrases (the case marker), or are independently required in the possessive constructions of the language (the possessor, the definite article, and the possessive agreement).

There is one element that is required in Hungarian possessive constructions in general, yet it cannot appear in anaphoric possessives: the possessedness marker $-j a /-j e /-a /-e$.

$$
\begin{aligned}
& \text { János-(nak a) csont-*(ja) } \\
& \text { John-DAT the bone-POSS } \\
& \text { John's bone }
\end{aligned}
$$

János-é-(*ja)

John-é-POSS

John's one

I suggest that this suffix cannot appear in anaphoric possessives because the pro-form corresponds to the Poss' constituent, and thus -ja/-je/-a/-e and the pronoun in effect compete for the same position. ${ }^{24}$

\footnotetext{
${ }^{24}$ Alternatively, the pro-form could correspond to the whole PossP. In this case the usual merge-in position of possessors in spec, PossP would be unavailable, and we would have to assume that -é possessors are inserted in their surface position in spec, Poss2P.
}

(i)

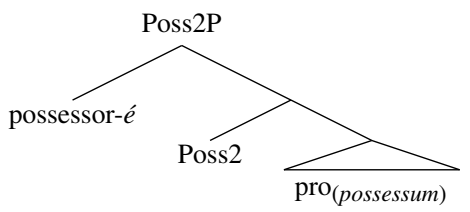

In either case, the pro-form already takes up the position where -ja/-je/-a/-e would be merged, so this suffix will not co-occur with the pro-form. 

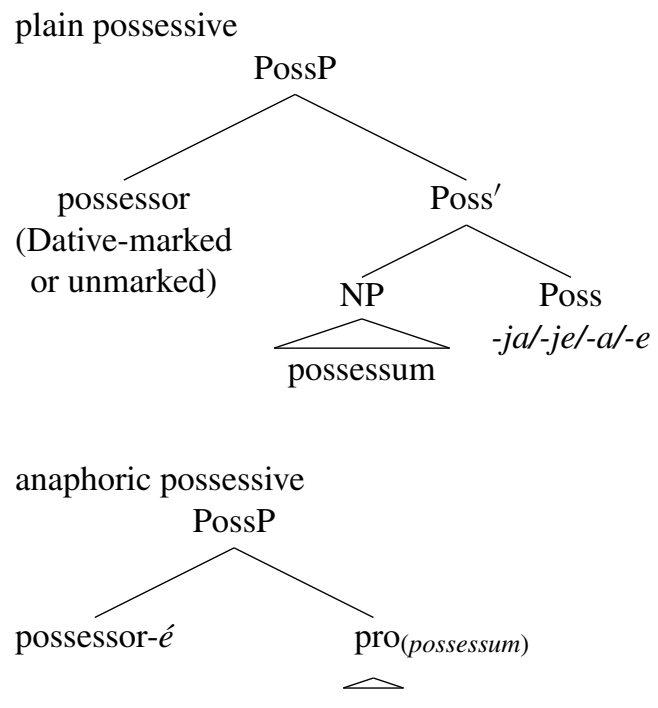

That pronouns may correspond to phrasal constituents is not new. Jackendoff (1977) proposes that English one corresponds to $\overline{\mathrm{N}}$, and Uriagereka (1995) and Corver and Delfitto (1999) suggest that clitic pronouns are D-elements that take a phonologically zero pro-NP complement. Weerman and Evers-Vermeul (2002) and Neeleman and Szendrói (2007) argue that overt and covert personal pronouns correspond to whole phrasal projections in several languages, and they derive the restricted modification of pronouns (as well as cross-linguistic and intra-linguistic variation thereof) from this assumption.

Weerman and Evers-Vermeul (2002) argue that Dutch pronouns that cannot cooccur with DP-internal material such as numerals and adjectives but can co-occur with D spell out some projection between NP and DP. Pronouns that co-occur neither with NP-modifiers nor D spell out DP, while some pronouns spell out the entire KP (this gives rise to the subject vs. object pronoun distinction). Neeleman and Szendrói (2007) suggest that pronouns which are agglutinating for both number and case spell out NP, pronouns agglutinating only for case spell out DP, and pronouns fusional for number and case spell out KP. Both accounts derive the co-occurrence restrictions between pronouns and NP-modifiers/nominal affixes from the size of pronouns: the bigger structure the pronoun stands for, the more restricted its modification is. In both approaches, the fact that the possessedness marker -ja/-je/-a/-e is obligatorily missing from Hungarian anaphoric possessives is most straightforwardly captured by the assumption that the pro-form spells out a category bigger than NP; in effect, it realizes the $\mathrm{N}(\mathrm{P})$ position and the Poss head fusionally, as a portmanteau. ${ }^{25}$

\footnotetext{
${ }^{25}$ If the lack of adjectives, classifiers, numerals, demonstratives, and participial clauses is also to be derived from the size of the pronoun, some non-standard assumptions have to be made about the structure. Under the standard assumption that possessors are merged in spec, PossP (Bartos 1999), the pro-form can be at most as big as Poss' ${ }^{\prime}$. Adjectives, classifiers, numerals, demonstratives, and participial clauses are all merged above PossP (i).
} 
In the preceding discussion I argued that Hungarian anaphoric possessives involve a pro-form, and this pronoun is responsible for the restriction on NP-modifiers in the construction. Let us now turn to Hungarian non-anaphoric possessives, which are freely modifiable.
a. Kér-em az-t
az öt szál piros rózs-át.
want-1SG that-ACC the five CL red rose-ACC 'I'd like those five red roses.'

(i) $\mathrm{KP}>$ DP $>$ Poss $2 \mathrm{P}>$ PrtcP $>$ DemP $>$ PrtcP $>$ NumP $>$ ClP/PrtcP $/ A P>$ PossP $>$ NP

This means that their absence does not follow from the size of the pronoun, and their unavailability must be attributed to some other factor.

If we assume that -é possessors are actually merged in their surface position in spec, Poss2P, and make the standard assumption that the plural of (121) (repeated below as (ii)) spells out the Num head, then the pronoun can be as big as the complement of Num.

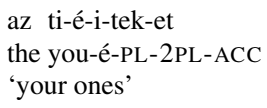

Then the size of the pronoun explains why the possessedness marker, classifiers, adjectives, and low participial clauses cannot occur in Hungarian anaphoric possessives (they are all merged in the complement zone of the Num head, which is now occupied the pro-form). The absence of numerals, demonstratives, and high participial modifiers is not accounted for by the size of the pronoun, because these are merged above the Num head, and their unavailability must be attributed to some other factor.

If the whole range of unavailable modifiers is to be explained in terms of pronoun size, then the pronoun must be as big as the complement of Poss2, because this is the smallest constituent that contains the merge-in site of all the excluded modifiers (the possessedness marker -ja/-je/-a/-e, adjectives, classifiers, numerals, demonstratives, as well as high and low participial clauses). For this analysis to work, two assumptions have to be made. First, possessors must be merged in their surface position in spec, Poss 2 (because the regular merge position of possessors in spec, PossP is unavailable due to the pronoun). Second, the $-i$ of (ii) and (iv), encoding plurality, cannot correspond to the Num head, because the Num position is also in the complement zone of Poss2, which is now taken up by the pronoun. One possibility is that only the singular anaphoric pronoun is lexicalized as $\emptyset$, and the $-i$ that we see in (iv) is actually the spellout of the plural anaphoric pronoun.

$$
\text { az ti-é-tek-et }
$$

the you-é-2PL-ACC

'yours/your one'

(v)

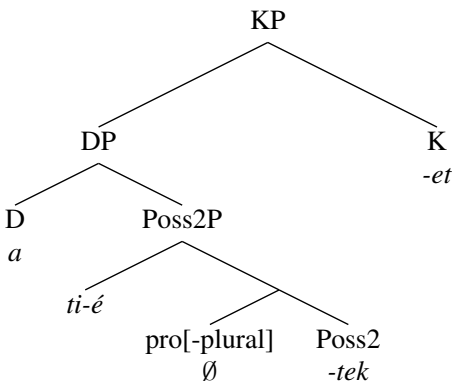

(iv)

az ti-é-i-tek-et

the you-é-PL-2PL-ACC

'your ones' (vi)

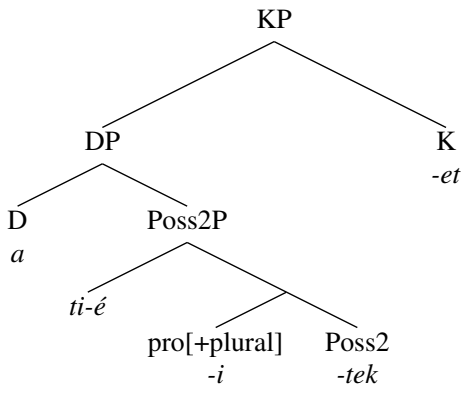


b. Kér-em az-t az öt szál piros-at. want-1SG that-ACC the five CL red-ACC 'I'd like those five red ones.'
a. Kér-em a két tegnap megrendelt mintás sál-at. want-1SG the two yesterday ordered marbled scarf-ACC 'I'd like the two marbled scarves ordered yesterday.'
b. Kér-em a két tegnap megrendelt mintás-at. want-1SG the two yesterday ordered marbled-ACC 'I'd like the two marbled ones ordered yesterday.'

I suggest that the nominal phrases in (129) and (130) admit NP-modifiers like any nominal phrase headed by a lexical noun because this is precisely what they are. The DPs of (129) and (130) bottom out in an ordinary lexical noun rather than a proform, and apart from the ellipsis of the head noun, there is nothing remarkable about them. The ellipsis of the nead noun can be implemented either as blocking of the regular vocabulary insertion process (Harley 2005), or as PF-deletion (Ticio 2003), or as the use of a lexical noun without descriptive (and possibly without phonological) features (Panagiotidis 2003b). As nothing crucial in this paper hinges on the particular implementation of NP-ellipsis, I will not look further into this issue. The point is that (129) and (130) are projected from an ordinary lexical noun, while -é possessives are projected form a pronoun.

Whether a language is able to use a pro-form in anaphoric possessives, and if so, in what contexts, that obviously depends on what sort of lexicon the language has. Only if there is an anaphoric pro-form in the lexicon of the language is the pronominal route available to create anaphoric NPs. If the vocabulary item inventory of a language has no anaphoric pro-form, then its only option to create NPs interpreted under identity with an antecedent is to use ellipsis. In the foregoing discussion I suggested that the lexicon of Hungarian does have an anaphoric pro-nominal. However, this pro-form is a portmanteau for $\mathrm{N}(\mathrm{P})$ and the Poss head. ${ }^{26}$ Therefore when this pro-nominal is employed, a possessor is also always introduced (via the Poss head), which leads to anaphoric possessives. Hungarian has no pro-nominal that is specified for $\mathrm{N}(\mathrm{P})$ only,

\footnotetext{
Another possibility is to keep the spellout of both the singular and the plural anaphoric pronoun as $\emptyset$, and treat the $-i$ of (iv) as some sort of agreement marker (see Dékány 2011 for an analysis along these lines).

We are thus in the following position. If we want to derive all the co-occurrence restrictions between the anaphoric possessum and NP-modifiers from pronoun size, the $-i$ of (ii) and (iv) cannot correspond to the Num head (if this $-i$ is the Num head, then the pro-form is not bigger than the complement of Num, and the fact that some NP-modifiers above NumP are also out will not be derived). Therefore we either have to accept that the plural that co-occurs with -é possessors is not the spellout of Num, or we have to dispense with the assumption that all co-occurrence restrictions between pronouns and their modifiers follow from the size of the pronoun (see Déchaine and Wiltschko 2002 as an example of how to do this).

As this work is primarily concerned with Hungarian anaphoric noun phrases, I do not consider it my task to explain why modifiers do not easily combine with pronouns. Whatever the reason is, it is a fact that Hungarian pronouns strongly resist modification, and the presence of a pro-form in anaphoric possessives derives that modification is heavily restricted in this construction, too.

${ }^{26}$ This can be modeled either as constituent spellout, like in Weerman and Evers-Vermeul (2002), Neeleman and Szendrői (2007), or as DM-style fusion of N and Poss, or as Nanosyntax-style 'spanning' of N and Poss. See Ramchand (2008), Svenonius (2012) for spanning analyses of vPs and PPs.
} 
therefore in order to create non-possessive anaphoric nominals, the language has to use ellipsis of a lexical noun. ${ }^{27}$

An in-depth analysis of the English anaphoric possessive construction is an enterprise that I will not engage in here, but it will be useful to briefly lay out the space of available options. Pronouns in English are somewhat more amenable to modification than in Hungarian, and this makes the situation less clear. While Hungarian pronouns cannot be modified at all (*Szeret-em/*szeret-lek az új téged 'like-1SG/like-1SG.2O the new you.ACC'), pronouns in English allow some modification (I like the new you). Therefore the fact that one admits NP-modifiers is compatible with both the ellipsis and the pro-analysis. At the same time, while modified regular pronouns is the exception rather than the rule even in English, one admits NP-modifiers rather freely.

\section{John's two white ones/these two white ones of John's found yesterday}

There is thus a contrast between the restricted modification of regular pronouns and the free modification of one. Harley's ellipsis analysis of one can capture this without auxiliary assumptions: English anaphoric possessives have a regular descriptive/lexical noun at their core, therefore NP-modifiers appear here just like in a garden variety noun phrase. The pro-analysis can capture this with the auxiliary assumption that the pronoun one in English is special: it has a different syntactic representation from that of other English pronouns, and this allows it to be freely modified. Déchaine and Wiltschko (2002), for instance, pursue this line of thinking and suggest that one is a pro-NP, while personal pronouns are pro- $\phi$ Ps and pro-DPs. ${ }^{28}$ Space considerations

\footnotetext{
${ }^{27} \mathrm{~A}$ valid question that arises here is the following: if the pro-route is available in a certain construction of a given language, is the ellipsis route also available for that construction? In other words, can the promethod and the ellipsis method be in free variation? Whether Universal Grammar allows for this possibility can only be determined on the basis of a cross-linguistic study. For the Hungarian anaphoric possessive, it appears to be the case that only the pro-route is available. If ellipsis were also possible, then we should be able to build a possessed noun that is modified by adjectives, classifiers, demonstratives, etc., and then we should be able to elide the possessed noun or the possessed noun plus possessedness marker sequence from that phrase. This would yield an DP where the possessum is anaphoric but it has overt modifiers, which simply does not materialize in Hungarian.

It turns out to be the case that there is a principled reason why ellipsis will not work in Hungarian anaphoric possessives. The pro-route of creating these structures uses just one vocabulary entry, a portmanteau, to lexicalize $\mathrm{N}$ and Poss. The ellipsis route, on the other hand, uses one lexical item to realize $\mathrm{N}$, and another one to realize Poss (plus deletes them at PF, or in Harley's approach, lexicalizes both positions with the $\emptyset$ item in the first place). It has long been appreciated in the literature that there is an economy principle regulating the spellout of structure, such that fewer vocabulary items are preferred over more vocabulary items (e.g. went blocks *goed). This principle is known under different names, such as Siddiqi's (2009) Minimize Exponence, Muriungi's (2009) Union Spellout Principle, or the Maximize Span of Nanosyntax; and it can be viewed as a special case of Cardinaletti and Starke's (1999) Minimise $\alpha$ (p. 204: "Minimise $\alpha$, up to crash, given a particular choice of interpretation"). The pro-route in Hungarian is thus more economical in terms of vocabulary item use than ellipsis, and therefore the former blocks the latter. Whether the pro-route also blocks the use of ellipsis when the two lead to equally economical vocabularization is an issue that remains for future research.

${ }^{28}$ An $N L L T$ reviewer points out that he is anaphoric to an individual (type <e>), while one is anaphoric to a property $(<e, t>)$, and this semantic difference might play a role in their modification possibilities. The semantic distinction, however, cannot be the whole story: both Hungarian -é constructions and English anaphoric one constructions are anaphoric to a property, but only the latter admit NP-modifiers.
} 
prevent me from a detailed evaluation of the deletion and the interpretation analysis of English one, and I will not pursue this issue any further here.

\subsection{The restriction on the distribution of Genitive possessors}

In Sect. 3 I identified five key properties of Hungarian anaphoric possessives. In Sect. 5 I argued that the Genitive analysis of -é derives the fact that -é does not combine with Dative possessors, and that -é takes part in demonstrative concord. In Sect. 6.1 I suggested that the modification of -é possessives is restricted because the anaphoric element is a pronoun, and the possessedness marker -ja/-je/-a/-e is excluded because the pronoun is a portmanteau for $\mathrm{N}(\mathrm{P})$ and Poss. There is one property that remains to be accounted for: the Genitive (-é) possessor appears only in anaphoric possessives, and conversely, anaphoric possessives allow only a Genitive $(-\hat{e})$ possessor. The relevant data are repeated below for the reader's convenience.

Non-anaphoric possessives: only morphologically unmarked or Dative-marked possessors

János kard-ja

John sword-POss

'John's sword'
János-nak a kard-ja

John-DAT the sword-POSS

'John's sword'

\footnotetext{
*János-é kard-ja

John-é sword-POSS

'John's sword'
}

Anaphoric and predicative possessives: only -é possessors
a. Whose sword is this?
b. János-é / *János / *János-nak
John-é / John / John-DAT
'John's'

It is hard to miss that Hungarian Dative and unmarked possessors are similar to English my, and Hungarian -é possessors are similar to English mine, cf. the contrast between my book and *mine book, and between *the book is my and the book is mine. The parallel, however, is not complete: $m y$ can occur in anaphoric noun phrases as long as it is followed by some overt DP-internal element other than one (cf. my purple one versus *my one), while in Hungarian Dative-marked and unmarked possessors cannot occur in anaphoric noun phrases under any circumstances. While I do not have a full-fledged account of this pattern, I will consider a few possible lines of thought, and attempt to give useful partial solutions if complete ones are out of reach.

Let us begin with the issue of why anaphoric possessives only allow -é possessors. It is well known that ellipsis is subject to two well-formedness conditions: recoverability of the elided material and 'licensing'. Licensing means that certain ellipsis configurations are excluded even when they would give a fully recoverable result; ellipsis can take place only in the context of specific DP-internal elements but not others. Consider NP-ellipsis in English, for instance. Simplifying matters significantly, 
NP-ellipsis without one is licensed by demonstratives, numerals and superlative adjectives, but not by ordinary adjectives and the definite article.

a. She made those cookies and he made these.

b. She made ten cookies and he made five.

c. She has an old edition but he has the newest.

d. *She made big cookies and he made small.

e. *The wine in this bottle is sweeter than the in that bottle.

It is also well known that what counts as a licensor for ellipsis is subject to crosslinguistic variation: in Dutch, for instance, it is adjectives with overt agreement that license ellipsis (see especially Bernstein 1993; Lobeck 1995; and Kester 1996 for discussion of ellipsis licensing). I suggest that Hungarian anaphoric possessives also need to be licensed in some way, and the only licensor is the Genitive possessor. Why unmarked and Dative-marked possessors should not be able to license ellipsis is something I am not able to reduce to an independent factor.

Let us now turn to the issue of why Genitive possessors will not appear in nonanaphoric noun phrases. Csaba Olsvay (personal communication) suggests that we might be dealing with a case of contextual allomorphy (a.k.a. context-sensitive spellout) here. Specifically, the Genitive case is spelled out as -é when it is followed by an anaphoric possessum, and elsewhere it is syncretic with the Dative case (-nak/nek).

Contextual allomorphy exists in Hungarian possessives elsewhere, too. The plural marker is spelled out as $-i$ when it is immediately preceded by a possessed noun, and it is $-k$ elsewhere (see also Bartos 1999).
a. motor-ok, ő-k
engine-PL he/she/it-PL
'engines', 'they'
b. János motor-ja-i/*motor-ja-k, János-é-i/*k
John engine-POSS-PL/engine-POSS-PL John-é-PL/PL
'John's engines, John's ones'

The $-i$ and $-k$ allomorphs have the same semantic contribution. That they really are two sides of the same coin can also be seen with demonstrative concord: a plural possessed noun will invariably take the $-i$ plural form, but its demonstrative modifier must bear the default $-k$ plural (138b).
a. ez-ek a motor-ok
this-PL the engine-PL
'these engines'
b. ez-ek/*ez-i a motor-ja-i
this-PL/this-PL the engine-POSS-PL
'these engines of his'

According to the suggestion of Olsvay (p.c.), something similar is going on with the case marking of possessors as well, except the two case allomorphs are conditioned by the anaphoric/non-anaphoric nature of the noun. At the present time, I see no simpler way of capturing the data than the one outlined here, and I will provisionally adopt this approach. 
A valid objection that could be raised against this analysis is that Dative-marked possessors are in the DP-peripheral escape hatch above the definite article, while -é possessors are below the article, in spec, Poss2.

$$
\begin{aligned}
& \text { nek-ünk a kabát-unk } \\
& \text { DAT-1PL the coat-1PL } \\
& \text { 'your coat' }
\end{aligned}
$$

$$
\begin{aligned}
& \text { a mi-é-nk } \\
& \text { the we-é-1PL } \\
& \text { 'ours' }
\end{aligned}
$$

Alexiadou et al. (2007) argue that cross-linguistically, possessors that end up in the escape hatch stop over in a position below DP. They call this position spec, AgrP; in this paper I called the same position spec, Poss2. This means that there is a direct link between the two possessor positions in (139) and (140): the latter corresponds to an intermediate landing site on the way to the former.

$$
\text { [escape.hatch } \operatorname{possessor}_{i}\left[\mathrm{DP} \mathrm{D} \text { [Poss2P } \mathrm{t}_{i} \text { Poss2 [ } \mathrm{t}_{i}\right. \text { possessum ]]]] }
$$

We see from (139) that case-marked possessors normally move to the left peripheral position of the DP, above the article. What we need to account for is why the casemarked possessor in anaphoric possessives must remain in the intermediate landing site spec, Poss2, and cannot make the final movement step to the escape hatch, producing (142).

$$
\begin{aligned}
& \text { *mi-é-nk a } \\
& \text { we-é-1 PL the } \\
& \text { 'ours' }
\end{aligned}
$$

I suggest that this is due to the independent factor that in Hungarian the article must be followed either by a noun or an NP-modifier.

$$
\begin{aligned}
& \text { a (friss) körté-ek-et } \\
& \text { the fresh pear-PL-ACC } \\
& \text { 'the (fresh) pears' }
\end{aligned}
$$

a friss-ek-et

the fresh-PL-ACC

'the fresh ones'

The article cannot be the final overt element in the noun phrase, nor can it support the stranded suffixes of an elided head noun. Compare (144), where the stranded suffixes lean onto the adjective, with (146), where the same suffixes try to lean onto the definite article.

$$
\begin{aligned}
& *_{\mathrm{a}} \\
& \text { the }
\end{aligned}
$$

$$
\begin{aligned}
& \text { *a-k-et } \\
& \text { the-PL-ACC }
\end{aligned}
$$

(145) and (146) can be rendered in a grammatical fashion only if the definite article is replaced by a demonstrative pronoun. Therefore what goes wrong with the final movement step of (141) in anaphoric possessives is that it leaves the article in the wrong configuration: the article either ends up being the final morpheme in the DP (if the anaphoric possessum does not leave behind any suffixes), or it ends up supporting the stranded plural, possessive agreement, and case suffixes of the anaphoric possessum. As the types of NP-modifiers in anaphoric possessives is extremely limited, in these constructions the article will only be followed by an NP-modifier if the possessor stays in spec, Poss 2 and does not move on to the escape hatch. 


\section{Conclusions}

In this paper I discussed the structure of Hungarian anaphoric possessives. I argued against the view held by traditional grammarians that the -é morpheme that appears on the possessor in these constructions has no direct equivalents in other languages. I compared three approaches to -é: the Genitive analysis, in which -é is a case-marker on the possessor, the Poss analysis, in which -é is the Poss functional head on the main projection line, and the pro analysis, in which -é stands in for the possessum and its possessedness marker. I argued that the Genitive analysis of -é derives the fact that -é takes part in demonstrative concord (all Hungarian case-markers do so), that certain types of pronouns can be Dative-marked and - $e$ marked but they cannot be unmarked as possessors (these pronouns need case), and it also explains why -é does not appear on Dative-marked possessors (a possessor cannot bear two cases in its own right). The alternative analyses cannot derive either of these properties, which led me to reject them, and to conclude that -é is the Genitive case of Hungarian.

The discussion of the Genitive and the Poss analyses of -é was reminiscent of the debate about the status of the Saxon Genitive in English. The Saxon Genitive has also been analysed as the Genitive case on the possessor (Jackendoff 1977; Chomsky 1986) and as a functional head that takes the possessum as its complement (Abney 1987; Kayne 1993, 1994; Zribi-Hertz 1997; den Dikken 1998; Bernstein and Tortora 2005). While consensus has been converging toward the functional head approach for the Saxon Genitive, I hope to have shown that the case approach to Hungarian -é is superior.

As for anaphoric nominals in Hungarian, I suggested that non-possessive anaphoric NPs are derived by ellipsis of a lexical noun, so these constructions admit the full range of NP-modifiers like ordinary DPs do. Anaphoric possessives, on the other hand, employ a pro-form. Pronouns in Hungarian strongly resist NP-modifiers, and by virtue of containing a pro element, anaphoric possessives also resist NP-modifiers. Those few modifiers that can appear are either compatible with the pronouns in the language, or are required by independent factors. I further proposed that the pro-form realizes $\mathrm{N}(\mathrm{P})$ and the Poss head in a fusional form. This blocks the ordinary Poss lexicalizer $-j a /-j e /-a /-e$ from anaphoric possessives, and allows a more economical way of creating anaphoric possessives than lexicalizing and eliding $\mathrm{N}$ and Poss separately.

The main argument for the pronominal analysis was built on the observation that lexical nouns allow modification but Hungarian pronouns do not, and anaphoric possessives also cannot be modified. In a language like Japanese, however, where pronouns can be modified much like lexical nouns (Noguchi 1997), looking at the modification of anaphoric nominals does not adjudicate the issue of whether they have a lexical noun or a pronoun at their core. In such languages this matter needs to be settled on the basis of other empirical evidence.

Acknowledgements I wish to thank Gillian Ramchand, Marcel den Dikken, Balázs Surányi, and Csaba Olsvay for useful discussion, and the audience of SinFonIJA-6 for feedback on an earlier version of this paper. Further thanks to Tibor Laczkó for discussing the LFG analysis with me, Orsolya Tánczos for her assistance with the Udmurt data, and two anonymous NLLT reviewers for valuable questions and comments. All disclaimers apply. 


\section{References}

Abney, Steven. 1987. The English noun phrase in its sentential aspect. PhD diss., Massachusetts Institute of Technology.

Alexiadou, Artemis, Liliane Haegeman, and Melita Stavrou. 2007. Noun phrase in the generative perspective. Berlin: Mouton de Gruyter.

Antal, László. 1961. A magyar esetrendszer [The Hungarian case sytem]. Vol. 29 of Nyelvtudományi értekezések. Budapest: Akadémiai Kiadó.

Asbury, Anna. 2005. Adpositions as case realizations: Structures and consequences. Leiden Papers in Linguistics 2 (3): 69-92.

Asbury, Anna. 2008. The morphosyntax of Case and adpositions. PhD diss., University of Utrecht.

Baker, Mark. 1985. The Mirror Principle and morphosyntactic explanation. Linguistic Inquiry 16: 373416.

Bartos, Huba. 1999. Morfoszintaxis és interpretáció. A magyar inflexiós jelenségek szintaktikai háttere. [Morphosyntax and interpretation. The syntactic background of Hungarian inflexional phenomena]. PhD diss., Eötvös University, Budapest.

Bartos, Huba. 2000. Az inflexiós jelenségek szintaktikai háttere [The syntacic background of inflexional phenomena]. In Strukturális magyar nyelvtan 3. Morfológia [Hungarian structural grammar 3. Morphology], ed. Ferenc Kiefer, 653-761. Budapest: Akadémiai Kiadó.

Bartos, Huba. 2001. Mutató névmási módosítók a magyarban: egyezés vagy osztozás? [Demonstrative modifiers in Hungarian: agreement or feature sharing?]. In Újabb tanulmányok a strukturális magyar nyelvtan és a nyelvtörténet köréból. Kiefer Ferenc tiszteletére barátai és tanítványai [Recent studies in Hungarian structural grammar and diachroic linguistics. In honour of Ferenc Kiefer, from his friends and students], eds. Marianne Barkó-Nagy, Zoltán Bánreti, and Katalin É. Kiss, 19-41. Budapest: Osiris.

Bernstein, Judy. 1993. The syntactic role of Word Markers in null nominal constructions. Probus 5: 5-38.

Bernstein, Judy B. 1997. Demonstratives and reinforcers in Romance and Germanic languages. Lingua 102: 87-113.

Bernstein, Judy B. 2001. Focusing the "right" way in Romance determiner phrases. Probus 13 (1): 1-29.

Bernstein, Judy B., and Christina Tortora. 2005. Two types of possessive forms in English. Lingua 115 (9): 1221-1242.

Bittner, Maria, and Ken Hale. 1996. The structural determination of Case and Agreement. Linguistic Inquiry 27 (1): 1-68.

Blake, Barry J. 1994. Case. Vol. 32 of Cambridge textbooks in linguistics. Cambridge: Cambridge University Press.

Blake, Barry J. 2001. Case, 2nd edn. Cambridge textbooks in linguistics. Cambridge: Cambridge University Press. First published in 1994.

Brugè, Laura. 2002. The positions of demonstratives in the extended nominal projection. In Functional structure in DP and IP, ed. Guglielmo Cinque, 15-53. Oxford: Oxford University Press.

Cardinaletti, Anna, and Michal Starke. 1999. The typology of structural deficiency: A case study of three classes of pronouns. In Clitics in the languages of Europe, ed. Henk C. Riemsdijk. Vol. 20-5 of Empirical approaches to language typology, 145-233. Berlin and New York: Mouton de Gruyter.

Chisarik, Erika, and John Payne. 2003. Modelling possessor constructions in LFG: English and Hungarian. In Nominals: Inside and out, eds. Miriam Butt and Tracy Holloway King. Studies in constraint-based lexicalism, 181-199. Stanford: CSLI Publications.

Chomsky, Noam. 1986. Knowledge of language: Its structure, origins and use. New York: Praeger.

Chomsky, Noam. 2000. Minimalist inquiries: the framework. In Step by step: Essays in honor of Howard Lasnik, eds. Roger Martin, David Michaels, and Juan Uriagereka, 89-155. Cambridge: MIT Press.

Chomsky, Noam. 2001. Derivation by phase. In Ken Hale: A life in language, ed. Michael Kenstowicz, 1-52. Cambridge: MIT Press.

Cinque, Guglielmo. 2005. Deriving Greenberg's Universal 20 and its exceptions. Linguistic Inquiry 36 (3): 315-332.

Corver, Norbert, and Denis Delfitto. 1999. On the nature of pronoun movement. In Clitics in the languages of Europe, ed. Henk van Riemsdijk. Vol. 20-5 of Empirical approaches to language typology, 799861. Berlin and New York: Mouton de Gruyter.

Csirmaz, Aniko. 2006. Anti-agreement: Features and locality. In Studies on agreement, eds. João Costa and Maria Cristina Figueiredo Silva. Vol. 86 of Linguistic aktuell / Linguistics today, 76-98. Amsterdam and Philadelphia: John Benjamins. 
Csirmaz, Aniko, and Éva Dékány. 2014. Hungarian is a classifier language. In Word classes: Nature, typology and representations, eds. Raffaele Simone and Francesca Masini. Current issues in linguistic theory, 141-160. Amsterdam and Philadelphia: John Benjamins.

Déchaine, Rose-Marie, and Martina Wiltschko. 2002. Decomposing pronouns. Linguistic Inquiry 33 (3): 409-442.

Dékány, Éva. 2011. A profile of the Hungarian DP. The interaction of lexicalization, agreement and linearization with the functional sequence. PhD diss., University of Troms $\varnothing$, Troms $\emptyset$.

Dikken, Marcel den. 1998. (Anti-)agreement in DP. In Linguistics in the Netherlands 1998, eds. Renée van Bezooijen and René Kager, 95-107. Amsterdam: John Benjamins.

Dikken, Marcel den. 1999. On the structural representation of possession and agreement. The case of (anti-)agreement in Hungarian possessed Nominal Phrases. In Crossing boundaries: Theoretical advances in Central and Eastern European languages, ed. István Kenesei, 137-178. Amsterdam: John Benjamins.

Dikken, Marcel den. 2006. Relators and linkers: The syntax of predication, predicate inversion, and copulas. Vol 47 of Linguistic inquiry monographs. Cambridge: MIT Press.

Dikken, Marcel den. 2007. Amharic relatives and possessives: Definiteness, agreement and the linker. Linguistic Inquiry 38 (2): 302-320.

É. Kiss, Katalin. 1998. Mondattan [Syntax]. In Új magyar nyelvtan [New Hungarian grammar], eds. Katalin É. Kiss, Ferenc Kiefer, and Péter Siptár, 17-184. Budapest: Osiris.

É. Kiss, Katalin. 2000. The Hungarian NP is like the English NP. In Approaches to Hungarian 7: Papers from the Pécs conference, eds. Gábor Alberti and István Kenesei, 119-150. Szeged: JATE.

É. Kiss, Katalin. 2002. The syntax of Hungarian. Cambridge: Cambridge University Press.

Fodor, István. 1999. Balázs Géza: magyar nyelvkultúra az ezredfordulón [Géza Balázs: Hungarian language culture at the turn of the century]. Magyar Nyelvór 123 (1): 136-139.

Guardiano, Christina. 2009. The syntax of demonstratives. A parametric analysis. Slides of a talk delivered at the 19th Colloquium on Generative Grammar, Vitoria, April 2009.

Harley, Heidi. 2005. One-replacement, unaccusativity, acategorical roots and Bare Phrase Structure. In Harvard working papers in linguistics 11, eds. Slava Gorbachov and Andrew Nevins, 59-78. Cambridge: Harvard Linguistic Department.

Hegedús, Veronika. 2013. Non-verbal predicates and predicate movement in Hungarian. PhD diss., University of Tilburg.

Jackendoff, Ray. 1977. X-bar syntax: A study of phrase structure. Vol. 2 of Linguistic inquiry monographs. Cambridge: MIT Press.

Julien, Marit. 2002. Syntactic heads and word formation. Oxford studies in comparative syntax. New York: Oxford University Press.

Kayne, Richard. 1993. Toward a modular theory of auxiliary selection. Studia Linguistica 47 (1): 3-31.

Kayne, Richard. 1994. The antisymmetry of syntax. Cambridge: MIT Press.

Kenesei, István. 1992. Az alárendelt mondatok szerkezete [The structure of embedded clauses]. In Strukturális magyar nyelvtan 1. Mondattan [Hungarian structural grammar 1. Syntax], ed. Ferenc Kiefer, 529-714. Budapest: Akadémiai Kiadó.

Kester, Ellen-Petra. 1996. Adjectival inflection and the licensing of empty categories in DP. Journal of Linguistics 32 (1): 57-78.

Kiefer, Ferenc. 2000. A ragozás [Inflection]. In Strukturális magyar nyelvtan 3. Morfológia [Hungairan structural grammar 3. Morphology], ed. Ferenc Kiefer, 569-619. Budapest: Akadémiai Kiadó.

Kornai, András. 1986. On Hungarian morphology. Candidate thesis, Research Institute for Linguistics, Hungarian Academy of Sciences. http://people.mokk.bme.hu/ kornai/Kand/newhm0.pdf.

Kornai, András. 1989. A főnévi csoport egyeztetése. [The concord of noun phrases]. Általános nyelvészeti tanulmányok 17: 183-211.

Korompay, Klára. 1992. A névszójelzés [Non-derivational nominal morphology]. In A magyar nyelv történeti nyelvtana II/1. A kései ómagyar kor. Morfematika [A historical grammar of Hungarian II/1. Late Old Hungarian. Morphotactics], ed. Loránd Benkő, 321-354. Budapest: Akadémiai Kiadó.

Kugler, Nóra. 2000. Az -é jeles (birtokosságbeli) egyeztetésről [On (possessive) -é agreement]. In A mai magyar nyelv leírásának újabb módszerei [New methods of describing contemporary Hungarian] IV, eds. László Büky and Márta Maleczki, 181-188. Szeged: Szegedi Tudományegyetem Általános Nyelvészeti Tanszék-Magyar Nyelvészeti Tanszék.

Laczkó, Tibor. 1995. The syntax of Hungarian noun phrases. A lexical-functional approach. Vol. 2 of Metalinguistica. Frankfurt am Main: Peter Lang. 
Laczkó, Tibor. 2007. On elliptical noun phrases in Hungarian. In Proceedings of the LFG07 Conference, University at Albany, State University of New York, eds. Miriam Butt and Tracy Holloway King, 323-342. Stanford: CSLI Publications. http://cslipublications.stanford.edu/LFG/12/lfg07.pdf.

Lander, Yury. 2009. Varieties of Genitive. In The Oxford handbook of case, eds. Andrej Malchukov and Andrew Spencer, 581-600. Oxford: Oxford University Press.

Larson, Richard K., and Sungeun Cho. 2003. Temporal adjectives and possessive DPs. Natural Language Semantics 11: 217-247.

Lipták, Anikó, and Andés Saab (2014, to appear). No N-raising out of NPs in Spanish: ellipsis as a diagnostic of head movement. Natural Language and Linguistic Theory.

Lobeck, Anne. 1995. Ellipsis. Functional heads, licensing, and identification. New York: Oxford University Press.

Lobeck, Anne. 2005. Ellipsis in DP. In The Blackwell companion to syntax: Blackwell reference online, eds. Martin Everaert and Henk van Riemsdijk. Blackwell.

Lotz, John. 1968. Grammatical derivability: The pronominal suffix - \{é\} 'that of ...' in Hungarian. Lingua 21: 627-637.

Malchukov, Andrej. 2009. Rare and 'exotic' cases. In The Oxford handbook of case, eds. Andrej Malchukov and Andrew Spencer, 635-648. New York: Oxford University Press.

Mártonfi, Attila. 2004. Az -é birtokjel névmási jellegéről [On the pronominal character of the possessive suffix -é]. In Még onnét is eljutni túlra [To get over even from there], eds. Mária Ladányi, Dér Csilla, and Hattyár Helga, 64-73. Budapest: Tinta Könyvkiadó.

Mel'čuk, Igor A. 1973. On the possessive forms of the Hungarian noun. In Generative grammar in Europe, eds. Ferenc Kiefer and Nicolas Ruwet. Vol. 13 of Foundations of language supplementary series, 315-332. Dordrecht: Reidel.

Moravcsik, Edith. 1995. Summing up suffixaufnahme. In Double case: Agreement by suffixaufnahme, ed. Frans Plank, 451-484. New York: Oxford University Press.

Muriungi, Peter Kinyua. 2009. The union spell-out principle. In Troms $\phi$ working papers on language and linguistics: Nordlyd 36.1, Special issue on nanosyntax, eds. Peter Svenonius, Gillian Ramchand, Michal Starke, and Knut Tarald Taraldsen, 191-205. Troms $\varnothing$ : University of Troms $\varnothing$.

Muromatsu, Keiko. 2003. Adjective ordering as the reflection of a hierarchy in the noun system. In Linguistic variation yearbook 2001, ed. Pierre Pica, 181-204. Amsterdam: John Benjamins.

Neeleman, Ad, and Kriszta Szendrői. 2007. Radical pro-drop and the morphology of pronouns. Linguistic Inquiry 38 (4): 671-714.

Noguchi, Tohru. 1997. Two types of pronouns and variable binding. Language 73 (4): 770-797.

Panagiotidis, Phoevos. 2000. Demonstrative determiners and operators: the case of Greek. Lingua 110 (10): 717-742.

Panagiotidis, Phoevos. 2003a. One, empty nouns, and theta-assignment. Linguistic Inquiry 34 (2): 281292.

Panagiotidis, Phoevos. 2003b. Empty nouns. Natural Language and Linguistic Theory 21 (2): 381-432.

Papp, István. 1955. A jelfunkció kérdéséhez. Magyar Nyelvór 51: 290-297.

Partee, Barbara H., and Vladimir Borschev. 2001. Some puzzles of predicate possessives. In Perspectives on semantics, pragmatics and discourse. A festschrift for Ferenc Kiefer, eds. István Kenesei and Robert M. Harnish, 91-117. Amsterdam: John Benjamins. Reprinted in Partee, Barbara H. 2004. Compositionality in formal semantics: Selected papers by Barbara H. Partee. Oxford: Blackwell Publishing, 292-315.

Plank, Frans. 1995. (Re-)introducing suffixaufnahme. In Double case: Agreement by suffixaufnahme, ed. Frans Plank, 3-110. New York: Oxford University Press.

Ramchand, Gillian. 2008. Verb meaning and the lexicon: A first phase syntax. Cambridge: Cambridge University Press.

Rebrus, Péter. 2000. Morfofonológiai jelenségek [Morphophonological phenomena]. In Strukturális magyar nyelvtan 3. Morfológia [Hungarian structural grammar 3. Morphology], ed. Ferenc Kiefer, 763949. Budapest: Akadémiai Kiadó.

Richards, Norvin. 2007. Lardil "case stacking" and the structural/inherent case distinction. Ms., MIT. http://ling.auf.net/lingBuzz/000405.

Ritter, Elizabeth. 1991. Two functional categories in Noun Phrases: Evidence from modern Hebrew. In Perspectives on phrase structure: Heads and licensing, ed. Susan D. Rothstein. Vol. 25 of Syntax and semantics, 37-62. San Diego: Academic Press.

Ritter, Elizabeth. 1992. Cross-linguistic evidence for Number Phrase. Canadian Journal of Linguistics 37: 197-218. 
Siddiqi, Daniel. 2009. Syntax within the word. Economy, allomorphy and argument selection in Distributed Morphology. Vol. 138 of Linguistik aktuell/Linguistics today. Amsterdam and Philadelphia: John Benjamins.

Simonyi, Zsigmond. 1914. A jelzók mondattana. Nyelvtörténeti tanulmány [The syntax of attributes. A study in diachronic linguistics]. Budapest: Magyar Tudományos Akadémia.

Svenonius, Peter. 2008. The position of adjectives and other phrasal modifiers in the decomposition of DP. In Adjectives and adverbs: Syntax, semantics and discourse, eds. Louise McNally and Christopher Kennedy. Vol. 19 of Oxford studies in theoretical linguistics, 16-42. Oxford: Oxford University Press.

Svenonius, Peter. 2012. Spanning. Ms., University of Troms $\emptyset$, Draft of April 25, 2012. http://ling.auf.net/ lingBuzz/001501.

Szabolcsi, Anna. 1983. The possessor that ran away from home. The Linguistic Review 3: 89-102.

Szabolcsi, Anna. 1992. A birtokos szerkezet és az egzisztenciális mondat [The possessive construction and existential sentences]. Budapest: Akadémiai Kiadó.

Szabolcsi, Anna. 1994. The Noun Phrase. In The syntactic structure of Hungarian, eds. Ferenc Kiefer and Katalin É. Kiss. Vol. 27 of Syntax and semantics, 179-275. New York: Academic Press.

Szabolcsi, Anna, and Tibor Laczkó. 1992. A fônévi csoport szerkezete [The structure of the noun phrase]. In Strukturális magyar nyelvtan 1. Mondattan [Hungarian structural grammar 1. Syntax], 181-298. Budapest: Akadémiai Kiadó.

Ticio, M. Emma. 2003. On the structure of DPs. PhD diss., University of Connecticut, Department of Linguistics.

Truswell, Robert. 2004. Attributive adjectives and the nominals they modify. Master's thesis, Oxford University.

Uriagereka, Juan. 1995. Aspects of the syntax of clitic placement in Western Romance. Linguistic Inquiry 26 (1): 79-123.

Weerman, Fred, and Jacquelina Evers-Vermeul. 2002. Pronouns and case. Lingua 112 (4): 301-338.

Williams, Edwin. 1981. Argument structure and morphology. The Linguistic Review 1: 81-114.

Zribi-Hertz, Anne. 1997. On the dual nature of the 'possessive' marker in Modern English. Journal of Linguistics 33 (2): 511-537. 